University of Nebraska - Lincoln

DigitalCommons@University of Nebraska - Lincoln

USDA Forest Service / UNL Faculty Publications U.S. Department of Agriculture: Forest Service --

National Agroforestry Center

2013

\title{
Changes in Forest Structure, Fuels and Potential Fire Behaviour Since 1873 in the Lake Tahoe Basin, USA
}

\author{
Alan H. Taylor \\ Pennsylvania State University - Main Campus, aht1@psu.edu \\ Anna M. Vandervlugt \\ Pennsylvania State University - Main Campus, annavandervlught@gmail.com \\ R. Stockton Maxwell \\ Radford University, rmaxwell2@radford.edu \\ Robert M. Beaty \\ CSIRO Sustainable Ecosystems, Matt.Beaty@CSIRO.au \\ Catherine Airey \\ Pennsylvania State University - Main Campus, cta5060@psu.edu \\ See next page for additional authors
}

Follow this and additional works at: https://digitalcommons.unl.edu/usdafsfacpub

Taylor, Alan H.; Vandervlugt, Anna M.; Maxwell, R. Stockton; Beaty, Robert M.; Airey, Catherine; and Skinner, Carl N., "Changes in Forest Structure, Fuels and Potential Fire Behaviour Since 1873 in the Lake Tahoe Basin, USA" (2013). USDA Forest Service / UNL Faculty Publications. 259.

https://digitalcommons.unl.edu/usdafsfacpub/259

This Article is brought to you for free and open access by the U.S. Department of Agriculture: Forest Service -National Agroforestry Center at DigitalCommons@University of Nebraska - Lincoln. It has been accepted for inclusion in USDA Forest Service / UNL Faculty Publications by an authorized administrator of DigitalCommons@University of Nebraska - Lincoln. 


\section{Authors}

Alan H. Taylor, Anna M. Vandervlugt, R. Stockton Maxwell, Robert M. Beaty, Catherine Airey, and Carl N. Skinner 


\title{
Changes in forest structure, fuels and potential fire behaviour since 1873 in the Lake Tahoe Basin, USA
}

\author{
Alan H. Taylor, Anna M. Vandervlugt, R. Stockton Maxwell, Robert M. Beaty, Catherine Airey \\ \& Carl N. Skinner
}

\begin{abstract}
Keywords
Fire behaviour; Fire exclusion; Forest reconstruction; Forest structure; Jeffrey pine; Lodgepole pine; Mixed conifer; Red fir; Restoration

Nomenclature

Hickman (1993)

Received 26 June 2012

Accepted 18 April 2013

Co-ordinating Editor: Kerry Woods

Taylor, A.H. (corresponding author, aht1@psu.edu), Vandervlugt, A.M. (annavandervlught@gmail.com) \& Maxwell, R.S. (rmaxwell2@radford.edu): Department of Geography, Pennsylvania State University, Earth and Environmental Systems Institute, University Park, PA, 16802, USA

Taylor, A.H. \& Airey, C. (cta5060@psu.edu): Pennsylvania State University, Interdepartmental Graduate Program in Ecology, University Park, PA, 16802, USA Beaty, R.M. (Matt.Beaty@CSIRO.au): CSIRO Sustainable Ecosystems, GPO Box 284, Canberra, ACT, 2601, Australia Skinner, C.N. (cskinner@fs.fed.us): USDA Forest Service Pacific Southwest Research Station, 3644 Avtech Parkway, Redding, California, 96002, USA

Maxwell, R.S.: Current address: Department of Geospatial Science,Radford University, Radford, VA, 24142, USA
\end{abstract}

\begin{abstract}
Questions: What were the characteristics of pre-Anglo-American (reference) forests before logging, grazing and fire exclusion, and how have they changed? What were the structural characteristics of canopy and surface fuels and potential fire behaviour in reference forests, and how do they compare to contemporary forests? How might information from reference conditions be used to inform current restoration and management practices?
\end{abstract}

Location: Lake Tahoe Basin in the Sierra Nevada, California and Nevada, USA.

Methods: Tree species composition, size structure, basal area, density, surface and canopy fuels, and potential fire behaviour were quantified for reference and contemporary conditions in 32 stands. This was accomplished by integrating field measurements and dendroecological techniques with vegetation and fire behaviour simulation models.

Results: Contemporary Jeffrey pine and mixed conifer forests had more trees, more basal area, smaller trees and a different size structure than the reference forest. Contemporary red fir and lodgepole pine forests also had more and smaller trees, but basal areas were similar to the reference. Red fir forests also shifted in composition towards lodgepole pine. Vegetation and fire models indicate that contemporary Jeffrey pine and mixed conifer forests have higher flame length, rates of spread, lower crowning and torching indices, and more passive crown fire than the reference forests. In contrast, contemporary red fir and lodgepole pine forests only had lower crowning and torching indices, and flame length and rate of spread were only higher with extreme weather and high surface fuel load.

Conclusions: Contemporary Jeffrey pine and mixed conifer forests deviate the most from the reference, and restoration objectives for these forests should emphasize density and basal area reduction of smaller diameter stems. Restoration objectives for red fir should shift species composition and reduce basal area by thinning smaller diameter lodgepole pine. For lodgepole pine forests, restoration objectives should include reduction of density and basal area of smaller diameter stems. Fire or other surface fuel treatments will be needed in all the forests to maintain lower fuel loads, albeit at different time intervals.

\section{Introduction}

Mixed forests of pine (Pinus spp.) and fir (Abies spp.) dominate the lower and upper montane zone of the Sierra Nevada in California, and these forests have undergone dramatic change since widespread Anglo-American settlement in the mid-19th century (McKelvey \& Johnston 1992; Franklin \& Fites-Kaufmann 1996). Forest changes are related to disruption of natural fire regimes, grazing and extensive logging, which began as early as the 1850s and 1860 s in the vicinity of gold and silver mining operations (Strong 1984; Beesley 1996). Fire played a key role in shaping species composition, stand structure and fuel characteristics (surface and canopy) in these forests before fire regime disruption in the late 19th or early 20th century. The reduction in fire frequency is thought to have had a 
greater influence on lower than upper montane forests (Skinner \& Chang 1996; van Wagtendonk \& Fites-Kaufman 2006). Before fire regime disruption in the Sierra Nevada and adjacent southern Cascades Mountains, there was a strong relationship between fire frequency and elevation, and fire return interval lengths in upper montane forests can be four- or more fold longer than those in lower montane forests (Taylor 2000; Scholl \& Taylor 2006, 2010; van Wagtendonk \& Fites-Kaufman 2006).

Several studies suggest that fire frequency and forest density in contemporary lower montane forests is outside the historic range of variability (Morgan et al. 1994; Taylor 2000; North et al. 2007; Beaty \& Taylor 2008; Scholl \& Taylor 2010). Historically, these forests burned at low or moderate severity at intervals of 5-25 yrs (Skinner $\delta$ Chang 1996; van Wagtendonk \& Fites-Kaufman 2006). The increase in density and build-up of surface and canopy fuels has increased the risk of high-severity fires, and in recent decades the area of lower montane forest burned at high severity has increased in some areas (Miller et al. 2009, 2012). Managers recognize the need to reduce the risk of extreme fire behaviour in highly altered forests and return them to a more fire resilient state (Brown et al. 2004; Graham et al. 2004; Noss et al. 2006). Studies that compare contemporary and reference forest structure and fire behaviour have been conducted in a few locations in the western USA (Fulé et al. 2004; Brown et al. 2008). This work has been limited to ponderosa pine (Pinus ponderosa Dougl.) forests and has emphasized estimating changes in forest canopy fuels and potential for crown fire behaviour. Although limited in application, the approach provides a strong foundation for guidance and justification of restoration management. On some public forest lands, there is an emphasis on managing future forests for conditions similar to those before Anglo-American forest disturbance (e.g. logging) and fire regime disruption (hereafter reference conditions) because these conditions are thought to decrease the risk of severe fire and increase fire resilience (Christopherson et al. 1996; Arno \& Fiedler 2005).

In the Lake Tahoe Basin (LTB) of the northern Sierra Nevada, forests were heavily logged (1873-1900) soon after initial Anglo-American settlement to support Comstock silver mining in Virginia City, Nevada (Strong 1984). Most contemporary forests in the LTB established after the heavy logging, but there are stands of uncut old-growth forest scattered throughout the basin (Barbour et al. 2002). In the LTB, there is a consensus among public land managers, citizen stakeholders and natural resource interest groups to reduce fire risk and increase forest resilience to wildfire via management that restores forests to preAnglo-American conditions (Christopherson et al. 1996; Elliot-Fisk 1996; Hymanson \& Collopy 2010). A recent wildfire (2007) in the LTB, with $>50 \%$ of the area burned at high severity, is thought to reflect forest changes caused by fire regime disruption and land-use history that increase forest susceptibility to high-severity fire. To guide and implement vegetation management, managers need quantitative estimates of reference forest characteristics, such as forest density and basal area, and the characteristics of surface and canopy fuels that influence fire behaviour.

In this study, we quantify the magnitude of change in forest structure, forest fuels and potential fire behaviour for forests in the LTB caused by Anglo-American land-use change. We accomplish this by integrating forest reconstruction techniques with vegetation and fire behaviour simulation models (cf. Fulé et al. 2004; Brown et al. 2008) to estimate and compare reference and contemporary forest structure and forest surface and aerial fuels for the four most widespread forest types dominated by Abies and Pinus. Specifically, we sought answers to the following questions: (1) what were the characteristics (e.g. species composition, density, basal area) of the reference forest? We expected contemporary forests to have a higher density and to have a different structure and species composition compared to the reference due to fire exclusion and disturbance. (2) What were the characteristics of canopy and surface fuels and potential fire behaviour in the reference forest? We expected that surface and canopy fuel characteristics that influence potential surface and crown fire behaviour to be higher in contemporary than reference forest. (3) How can this information be used in vegetation management to achieve a restoration goal of reference period conditions? To answer these questions we developed new quantitative estimates of surface and canopy fuel characteristics and fire behaviour for previously identified reference and contemporary Jeffrey pine, red fir and lodgepole pine forests on the east shore of Lake Tahoe (Taylor 2004). Reference and contemporary forest data for these stands included only estimates of forest density and basal area and they were developed from samples of wellpreserved 19th century stumps and contemporary forests on the same sites. We also develop new estimates of reference and contemporary forest structure and surface and canopy fuel characteristics in unlogged old-growth stands of mixed conifer forests on the west shore of Lake Tahoe described by Beaty $\&$ Taylor (2007). These data are then synthesized to provide guidance for restoration management for the dominant forest types in the LTB.

\section{Methods}

\section{Study area}

People have been using the forests in the LTB for at least 8,000 yrs. The Washoe migrated west from the Great Basin annually to hunt, fish and gather food (Elliot-Fisk 1996; Lindström 2000). Anglo-Americans first travelled through 


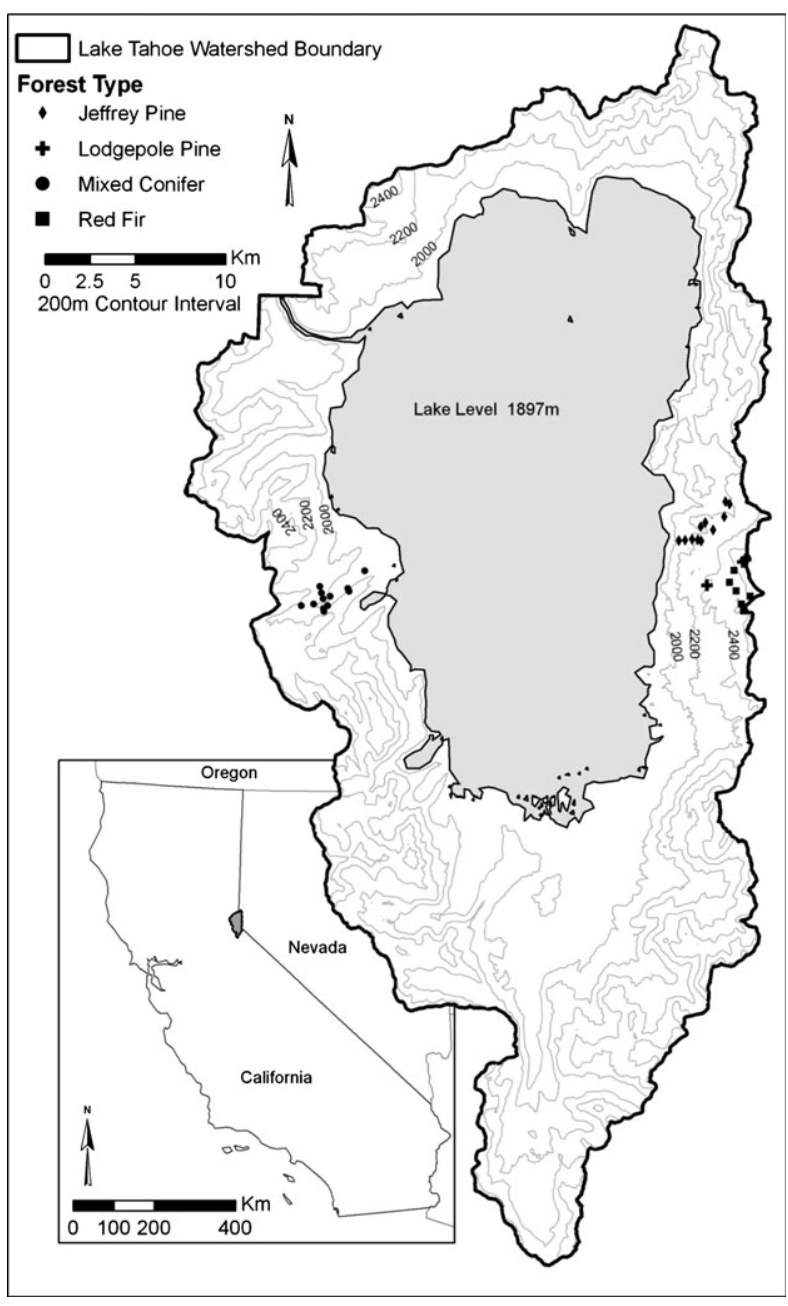

Fig. 1. Location of study area and forest plots in the Lake Tahoe Basin. Forest type is indicated by symbol (diamond = Jeffrey pine, cross $=$ lodgepole pine, circle $=$ mixed conifer, square $=$ red fir).

the region in 1844, but the basin was not settled until the 1860s. The discovery of the Comstock Lode silver ore deposit in 1859 initiated intense logging in the basin to provide timber for mining operations (Strong 1984). Logging reduced the area of forest by $67 \%$ by the end of the 19th century and subsequent 20th century logging reduced old-growth forests to $<2 \%$ of the LTB (Barbour et al. 2002).

The climate in the LTB is characterized by cool, wet winters and warm, dry summers. Most precipitation (80\%) falls as snow in the winter and more precipitation falls on the west that east shore (Barbour et al. 2002). Mean monthly temperatures at Tahoe City, California, range from $-2{ }^{\circ} \mathrm{C}$ in January to $16{ }^{\circ} \mathrm{C}$ in August, and mean annual precipitation is $78.4 \mathrm{~cm}$.

Forest structure and fuel load in mixed conifer forest were measured in Sugar Pine Point State Park (Fig. 1,
Appendix S1). Mixed conifer forests (MC) may be co-dominated by any of six species including incense cedar (Calocedrus decurrens [Torr.] Florin), sugar pine (Pinus lambertiana Douglas), Jeffrey pine (Pinus jeffreyi Balf.), red fir (Abies magnifica A. Murray bis), western white pine (Pinus monticola Douglas ex D. Don) or white fir (Abies concolor [Gord. \& Glend.] Lindl. ex Hildebr.) (Beaty \& Taylor 2007). Mixed conifer stands were sampled on sites that ranged in elevation from 1948-2109 m a.s.l.

Forest structure and fuel loads in forests that were logged in the 19th century were sampled in a 2900-ha area on the east shore of Lake Tahoe, where tree species distribution is controlled by elevation and soil moisture (Fig. 1, Appendix S1; Barbour \& Minnich 2000). Jeffrey pine (JP) is the dominant species at low elevations (1900$2000 \mathrm{~m}$ ), and mixed forests of Jeffrey pine and white fir occur above the Jeffrey pine zone. Above 2300 m, Jeffrey pine-white fir forest is replaced by mixed forests of red fir and western white pine (RF). Forests dominated by lodgepole pine (Pinus contorta var. murrayana Douglas ex Loudon; LP) occupy harsh or wet sites above or within the RF zone. Stands were sampled at elevations ranging from 1980-2620 m. The primary criterion for plot site selection in logged stands was the presence of a population of wellpreserved cut stumps. Preservation ranged from stumps with little sap- or heart-wood decay, to moderately decayed stumps still encased in bark. Site location and characteristics are given in Fig. 1 and Appendix S1, and further details on logging dates and fire regimes can be found in Taylor (2004).

\section{Field sampling}

\section{Forest structure}

Forest structure and fuel loads in unlogged MC forests were sampled in 12 plots with various site conditions. All plots were $50 \times 100 \mathrm{~m}$, except two, which were larger $(70 \times 100 \mathrm{~m})$ because of low stand density. The plots were established in 1999, and along with fire scar samples, were used to examine how fire regimes and forest structure vary with environmental setting and how fire regimes influenced tree regeneration (Beaty \& Taylor 2007). Site location and characteristics are given in Fig. 1 and Appendix S1, and further details on fire regimes can be found in Beaty \& Taylor (2007). In each plot, trees $(\geq 5.0 \mathrm{~cm}$ diameter at breast height $[\mathrm{DBH}])$, live saplings $(>1.4 \mathrm{~m}$ tall and $<5.0 \mathrm{~cm} \mathrm{DBH})$ and live seedlings $(0.5-1.4 \mathrm{~m}$ tall and $<5.0 \mathrm{~cm} \mathrm{DBH})$ were mapped and measured in $10 \times 10 \mathrm{~m}$ grids cells. The condition (live or dead), location $(x, y)$, $\mathrm{DBH}$, height class (dominant, co-dominant, intermediate, suppressed) and species of trees and $\operatorname{logs} \geq 5 \mathrm{~cm} \mathrm{DBH}$ rooted in a cell were recorded. Reference period tree age structure was determined by coring all trees $>40 \mathrm{~cm} \mathrm{DBH}$ 
to the pith at $30 \mathrm{~cm}$ above the soil surface and all trees in randomly selected $10 \times 10 \mathrm{~m}$ cells until $\geq 20 \%$ of all trees in the contemporary forest were cored. In 2010, we remeasured the plots to collect additional data needed to reconstruct reference forest characteristics and to measure forest fuels. In each $10 \times 10 \mathrm{~m}$ sample grid, we measured the $\mathrm{DBH}$, height $(\mathrm{m})$, height to dead crown base $(\mathrm{m})$ and height to live crown base $(\mathrm{m})$ of all live and dead standing trees. We also recorded the relative height class (dominant, co-dominant, intermediate, suppressed) of all live and dead standing trees and visually classified dead trees by stage and decay class (Maser et al. 1979). Downed logs were mapped, classified by decay class, identified to species and measured at DBH.

Forest structure in logged stands on the east shore was sampled in 1996 in a similar manner. Twenty $(\mathrm{JP}=11$, $\mathrm{RF}=6, \mathrm{LP}=3)$ 0.5-ha $(100 \times 50 \mathrm{~m})$ plots were established to characterize forest conditions (Fig. 1, Appendix S1). Forest structure and composition was determined by measuring and mapping live and dead trees $(\geq 10 \mathrm{~cm} \mathrm{DBH})$ and preserved Comstock period cut stumps in $10 \times 10 \mathrm{~m}$ grids established in each plot. Saplings (stems $>1.4 \mathrm{~m}$ tall and $<10 \mathrm{~cm} \mathrm{DBH}$ ) in each cell were also counted.

\section{Forest fuels}

Surface and canopy fuels in MC forests were estimated using three methods (1) measurement of down and dead woody fuel using planar intercept transects (Brown 1974); (2) estimates of down and dead woody fuel using Photo Series (Blonski \& Schramel 1981); (3) estimates of down and dead woody fuel using the Fire and Fuels Extension of the Forest Vegetation Simulator (FFE-FVS http://www.fs. fed.us/fmsc/fvs/whatis/index.shtml). For the planar intercept method, surface fuels were measured along four 17-m transects at four systematically located points in each plot (Brown 1974). Transect direction was determined using random azimuths from each point. Fuel Photo Series estimates of fuel load were made at the same four points using the Southern Cascades and Northern Sierra Nevada photo series developed by Blonski \& Schramel (1981). FFE-FVS estimates of surface fuels by time-lag size class were generated using the western Sierra Nevada variant of FFE-FVS from the list of trees and tree characteristics for each plot. Surface fuel loads for contemporary forests in logged stands on the east shore were estimated using only the photo series and FFE-FVS methods.

\section{Forest reconstruction}

\section{Stand structure}

Forest structure and composition were reconstructed for the year 1873, 2 yrs after the last fire scar date on the east shore (Taylor 2004) and the last fire scar date in eight of 12 MC plots on the west shore (Beaty \& Taylor 2007). An earlier date was not chosen because wood needed to reconstruct earlier reference conditions would have been consumed in the 1873 fire. Forest structure and composition in the MC plots were reconstructed using the method described by Fulé et al. (1997) modified for conditions in MC forests (North et al. 2007; Scholl \& Taylor 2010). This included the following steps summarized from Fulé et al. (2002): (1) the diameter of live trees in 1873 was determined by subtracting the radial growth from 1873 to the contemporary sampling date (complete tree cores); (2) the diameter of live trees in 1873 was determined by subtracting species-specific average annual radial growth, estimated from cored trees $>100$ yrs old $(n=1509)$, from the measured diameter for each year from 1873 to the contemporary sampling date (incomplete cores); (3) the death date for dead and down trees was estimated using tree decay class and cumulative species-specific decomposition rates from diameter-dependent equations (Thomas 1979; Rogers 1984); (4) decomposition rates were calculated for each species for slow (25th percentile), median (50th percentile) and fast (75th percentile) decomposition to evaluate the sensitivity of estimated death dates and forest structure to decomposition rates; and (5) the diameter of dead and down trees alive in 1873 was estimated by subtracting species-specific average annual radial growth from the measured diameter for each year from 1873 to the estimated death date, and then adjusting diameters for bark loss.

\section{Forest fuels}

Quantifying reference period forest fuels was a challenge since fuels present in 1873 were likely to have decomposed completely. Consequently, we estimated surface fuel abundance in each plot using three indirect methods. These methods were: (1) Photo Series, (2) FFE-FVS (http://www.fs.fed.us/fmsc/fvs/whatis/index.shtml) and (3) the Tables Method based on fuel deposition rates reported in van Wagtendonk \& Moore (2010).

For the Photo Series method, we matched reference period stand composition and structure to historic photographs ( $n=15$ photos) of similar forest types in the nearby $(<175 \mathrm{~km})$ southern Cascades that were never logged and had experienced $<20$ yrs of fire suppression (Taylor 2000). Fuel loads in the photographs were then estimated using the southern Cascades Northern Sierra Nevada Photo Series (Blonski \& Schramel 1981). For the FFE-FVS method, we estimated fuel loads using the tree list of the reconstructed forest. Fuel was then accumulated in each plot for the period equal to the median fire return interval from fire scar records (grand median 
$\mathrm{JP}=11 \mathrm{yrs} ; \quad \mathrm{MC}=11 \mathrm{yrs} ; \quad \mathrm{RF}=76 \mathrm{yrs} ; \quad \mathrm{LP}=50 \mathrm{yrs})$ (Taylor 2004; Scholl \& Taylor 2006; Beaty \& Taylor 2007) and output by time-lag size class.

For the Tables Method, each tree in the reconstructed forest was assumed to deposit an amount of fuel proportional to its basal area, which was derived from table values in van Wagtendonk \& Moore (2010). Fuel was then accumulated as in the FFE-FVS method and fuel load for each time-lag class was determined by summing values for all trees.

\section{Potential fire behaviour}

Potential fire behaviour for contemporary and reference forests was simulated using Crown Mass in Fuels Management Analyst (www.fireps.com/fmanalyst3/index. htm). Crown Mass calculates potential fire behaviour and some first-order fire effects from tree lists that include tree species, DBH, tree height, crown ratio and structural stage. Estimates of crown fuel variables in all plots were made using tree lists and the Crown Mass routine in FMA. For all reference plots (JP, MC, RF, LP) and contemporary plots on the east shore (JP, RF, LP), crown ratio and tree height were estimated using tree lists and FVS. The crown fuel variables for these plots were then estimated using tree lists and the Crown Mass routine in FMA. For contemporary MC plots, we had field measurements of tree height and crown ratio and used these measurements in both FVS and FMA to estimate crown fuel variables.

Surface fuel estimates for time-lag classes for each method were then input to FMA, which compared the similarity of our estimates to values for standard fuel models (i.e. Anderson 1982; Scott \& Burgan 2005). We then selected the range of fuel models for each forest type identified by FMA to bracket the range of potential behaviour of fire (surface and crown) that might be expected from the variability in our fuel estimates. The same fuel models were used for reference and contemporary forest to identify relative differences between reference and contemporary fire behaviour. Standard surface fuel models were used to estimate potential fire behaviour because, in contrast to custom fuel models, they have been calibrated with observed fire behaviour under conditions similar to those simulated (Rothermel \& Rinehart 1983; Burgan \& Rothermel 1984).

Fire intensity depends on weather conditions and fuel moisture content (Reinhardt \& Crookston 2003) so we estimated potential fire behaviour for the fire season (1 June to 31 September) using three different fuel moisture and wind speed scenarios. We used fuel moisture and wind speeds for the 80th, 90th and 98th percentile weather conditions (Fire Family Plus) from the Truckee remote automated weather station (RAWS) to represent moderate, severe or extreme fire weather conditions (www.firemodels.org/index.php/national-systems/fire familyplus).

We chose five variables from the simulations to represent potential fire behaviour: (1) rate of spread, (2) flame length, (3) crowning index (minimum wind speed to support active crown fire), (4) torching index (wind speed at $6.06 \mathrm{~m}$ above the ground needed to ignite the crown), (5) categorical fire type (surface, passive crown, active crown). The last variable provides a measure of how fire hazard may have changed in contemporary forests compared to reference forests. Simulations were computed for each of the three weather conditions and each standard fuel model.

\section{Comparison of reference and contemporary conditions}

Comparison of reference and contemporary forest characteristics were made using non-parametric statistical tests (Sokal \& Rohlf 1995). Differences in density, basal area, quadratic mean diameter, fuels and fire behaviour characteristics were identified using the Kruskal-Wallis $\mathrm{H}$ test. Diameter distributions, or the frequency of stems in each size class, for reference and contemporary forests were compared using a Kolmogorov-Smirnoff two-sample test.

Variation in simulated fire behaviour in reference and contemporary forests related to weather and fuels model was also identified by ordinating fire behaviour variables using principal components analysis (PCA; McCune et al. 2002). Average values for each variable (ROS, FL, CI, TI) for the three weather scenarios, and the three fuel types, were calculated for each forest type and then standardized to ordinate potential fire behaviour in contemporary and reference forests.

\section{Results}

\section{Forest reconstruction}

The forest reconstruction method for MC forests was not sensitive to variation in decomposition (Appendix S2). There were no differences in the reconstructed average density, basal areas or quadratic mean diameter for the low, moderate and high decomposition models $(P>0.05$, Kruskal-Wallace H test). However, on average, $40-44 \%$ of reference stems were trees that died in the mid- to late 20 th century and were reconstructed to 1873 . Therefore, the lack of inclusion of downed and dead wood in the forest reconstruction would greatly underestimate stand density and basal area (Appendix S2). Given the low sensitivity of the reconstruction method to variation in the decomposition model, only the 50th percentile model is reported. 

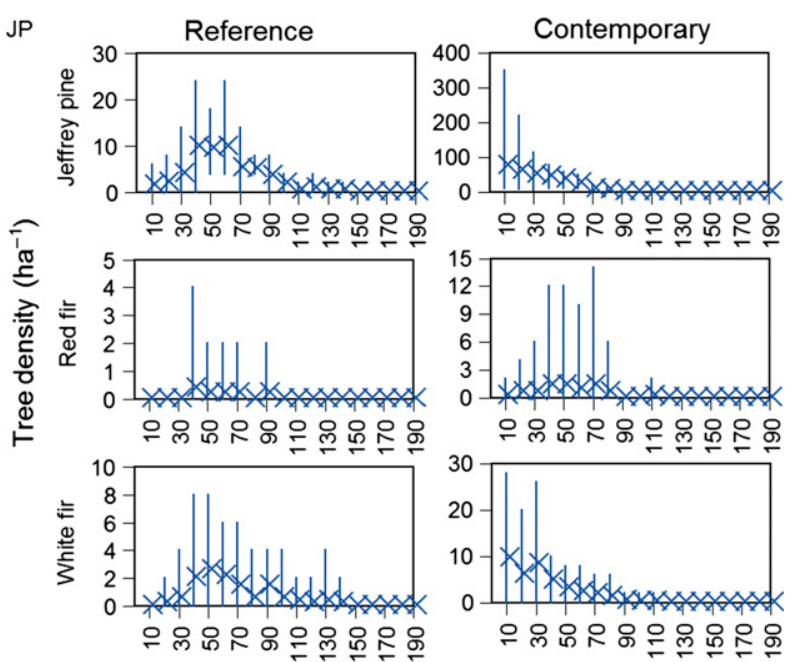

Size class $(\mathrm{cm})$

Fig. 2. Mean and range of tree (stems $>10 \mathrm{~cm}$ in diameter) density in reference and contemporary Jeffrey pine forests $(n=11)$ in the Lake Tahoe Basin, USA. The ' $X$ ' symbol denotes the mean, and the vertical line depicts the range for each size class. Note the $y$-axis scale is different on each graph. Bins are classified by the lowest DBH included in the bin. For example, the $10 \mathrm{~cm}$ bin includes trees 10 to $20 \mathrm{~cm} \mathrm{DBH}$. Every other bin is labeled on the $x$-axis.

\section{Reference and contemporary forest structure}

Reference and contemporary JP forests were different (Fig. 2, Appendix S3). Contemporary forests had five-fold more trees $(P<0.001), 1.8$-fold more basal area $(P<0.001)$, and trees $60 \%$ the size $(P<0.05)$ of the reference forest. Contemporary forests also had a different size class distribution than the reference forest $(P<0.05)$. There were few trees $<40 \mathrm{~cm}$ in diameter in the reference forest (Fig. 2).

Reference MC forests were different to the contemporary forests (Fig. 3, Appendix S3). Contemporary forests had three-fold more trees $(P<0.001), 1.9$-fold more basal area $(P<0.001)$ and 4.4 -fold more white fir than the reference forest $(P<0.001)$, although overall quadratic mean diameter $(\mathrm{QMD})$ was similar $(P>0.05)$. The shape of the size class distribution for the reference forest was also different than for the contemporary forest $(P<0.001$; Fig. 3). In the reference forest, trees were more evenly distributed among size classes than in contemporary forests, which had a higher density of trees, especially white fir, in the smallest size classes.

Reference RF forests were different to contemporary forests (Fig. 4, Appendix S3). Contemporary forests were 3.3-fold denser $(P<0.05)$ than reference forests, but basal area was similar $(P>0.05)$. Contemporary forests also had a different composition. Red fir and western white pine
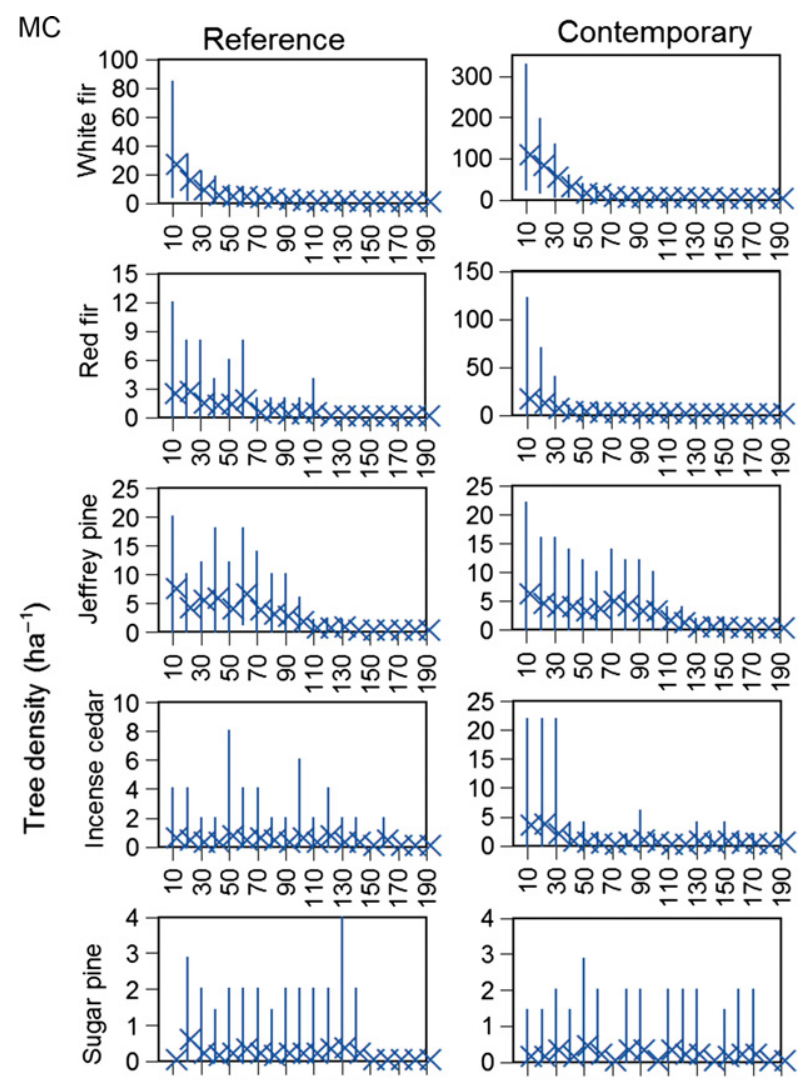

으응ㅇㅇ요은유윳요
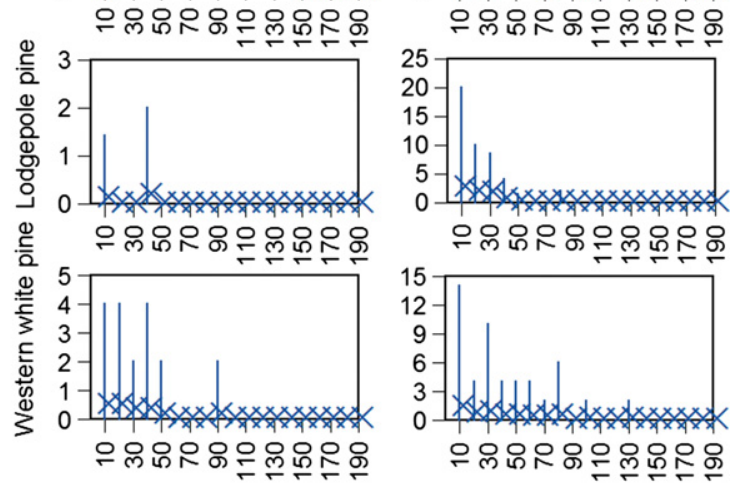

우융융ㅇㅇ으으유요용

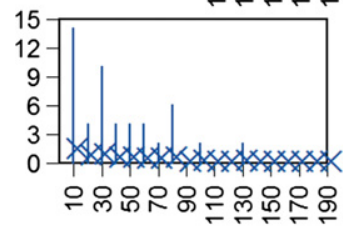

Size class $(\mathrm{cm})$

Fig. 3. Mean and range of tree (stems $>10 \mathrm{~cm}$ in diameter) density in reference and contemporary mixed conifer forests $(n=12)$ in the Lake Tahoe Basin, USA. Format as in Fig. 2.

comprised $>50 \%$ of the trees in the reference forests, while $>50 \%$ of the trees in the contemporary forest were lodgepole pine. In fact, contemporary forests have 19.6-fold more $(P<0.05)$ lodgepole pine than reference forests. The size class distributions of the contemporary and reference forest were also different $(P<0.001)$. Reference red fir, western white pine and lodgepole pine trees were larger in diameter than contemporary trees and there were few reference trees $<30 \mathrm{~cm}$ in diameter (Fig. 4). 


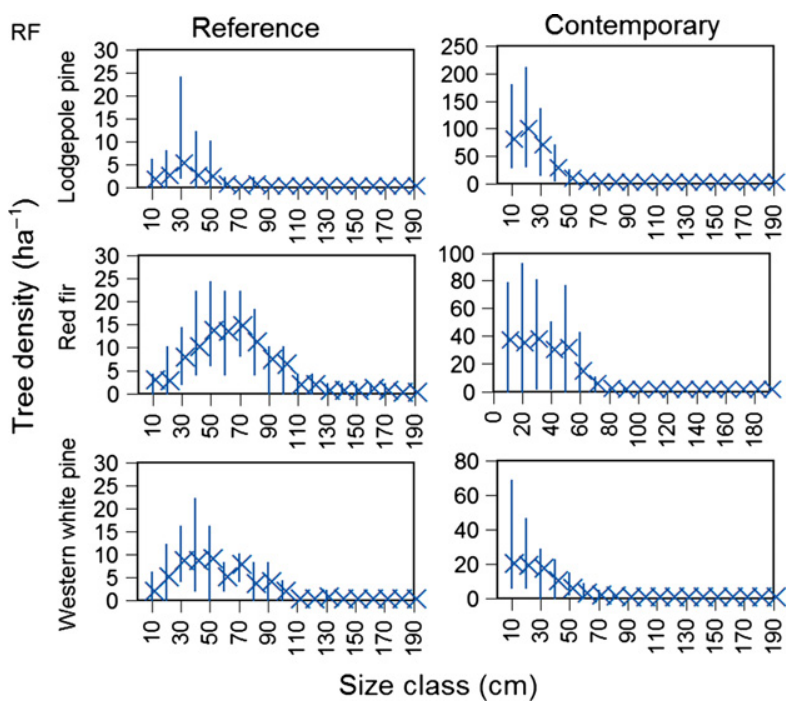

Fig. 4. Mean and range of tree (stems $>10 \mathrm{~cm}$ in diameter) density in reference and contemporary red fir forests $(n=6)$ in the Lake Tahoe Basin, USA. Format as in Fig. 2. Not shown for contemporary forests are Jeffrey pine in the $10-\mathrm{cm}$ (mean $=1.3$, range $0-4)$ and 30- $\mathrm{cm}$ (mean $=0.7$, range $0-2$ ) size classes, and white fir in the $20-\mathrm{cm}$ (mean $=0.3$, range $0-2$ ) and $30-\mathrm{cm}$ (mean $=0.3$, range $0-2$ ) size classes.

Reference LP forests had one-third the trees of the contemporary forests $(P<0.05)$ but their basal areas were similar $(P>0.05$; Fig. 5, Appendix S3). Trees in the reference forest were also twice as large as those in the contemporary forest $(P<0.05)$ and trees were present in a wider range of size classes (Fig. 5). There were few reference trees $<30 \mathrm{~cm}$ in diameter.

\section{Reference and contemporary fuels}

Estimates of total surface fuel $(1-, 10-, 100-h r)$ varied by method and forest condition (Table 1). All methods gave similar estimates $(P>0.05)$ of total reference surface fuel load for JP and MC forests. Moreover, reference surface fuel loads for these forest types were lower $(P<0.05)$, except JP Photo Series, than in contemporary forest. Estimates of FFE-FVS and the Photo Series for contemporary MC were also similar $(P>0.05)$ to planar intercept estimates. In reference RF forests, the FFE-FVS and fuel deposition rate estimates were similar $(P>0.05)$ and so were Photo Series and fuel deposition rate estimates for reference LP $(P>0.05)$. Estimates of contemporary RF surface fuels were similar or higher than reference $\mathrm{RF}$, depending on the method. Differences in reference and contemporary surface fuels for LP were inconsistent among methods.

Canopy fuel characteristics in reference forests differed compared to contemporary forests (Table 2). Canopy bulk
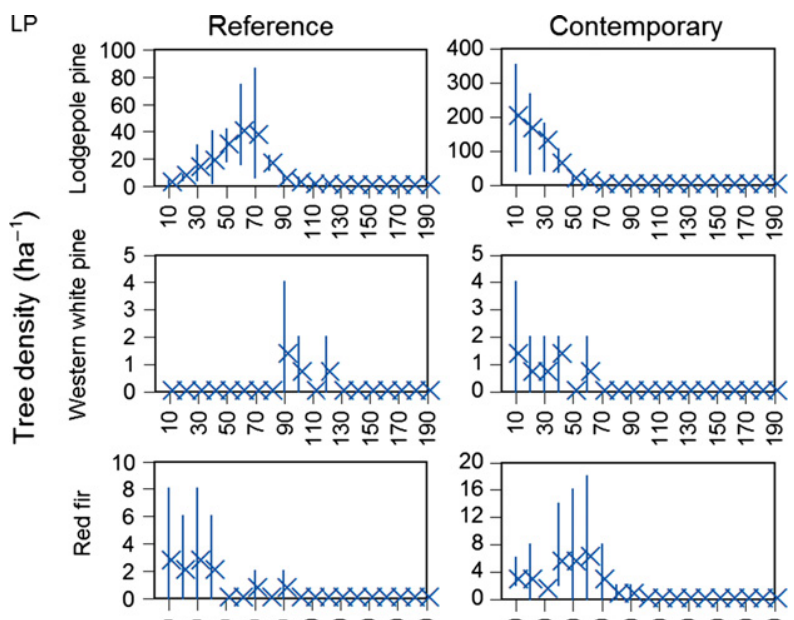

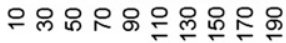

Size class $(\mathrm{cm})$

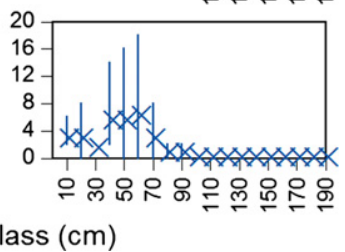

Fig. 5. Mean and range of tree (stems $>10 \mathrm{~cm}$ in diameter) density in reference and contemporary lodgepole pine $(n=3)$ in the Lake Tahoe Basin, USA. Format as in Fig. 2. Not shown for contemporary forests are Jeffrey pine in the 40-cm (mean $=0.7$, range $0-2$ ) size class, and white fir in the $30-\mathrm{cm}$ (mean $=1.0$, range $0-2$ ) size class.

density (CBD) was lower $(P<0.05)$ for JP, MC and RF, and canopy base height $(\mathrm{CBH})$ was higher $(P<0.05)$ for reference than in contemporary forests. Stand height was only different for contemporary RF, which was shorter than for the reference forest.

\section{Reference and contemporary potential fire behaviour}

Fire behaviour in all reference and contemporary forest types was strongly influenced by fire weather and fuel moisture conditions (Table 3). Measures of fire behaviour including flame length, rate of spread, crowning index and torching index, became more extreme when weather conditions were more extreme, and this was true for reference and contemporary forest conditions for all forest types (Fig. 6a,b, Appendix S4). In JP forests, fire behaviour was least extreme with TL4 and most extreme with FBM9, and fire behaviour with TL7 was intermediate. In MC forests, fire behaviour was most extreme with fuel model FBMI0 and least extreme with TL3. In RF and LP forests, fire behaviour was least extreme with TL4 and most extreme with TL7.

Fire behaviour in contemporary JP and MC forests was higher than in reference forests (Fig. 6a,b, Appendix S4). Rate of spread, flame length, crowning index and torching index were more extreme $(P<0.05)$ in contemporary than reference forests for all fuel models and weather conditions, with few exceptions. This pattern is also reflected in potential fire type. Reference JP and 
Table 1. Mean (range) surface fuel characteristics estimated for reference (Ref.) and contemporary (Con.) forests in the Lake Tahoe Basin, USA, using the fire and fuels extension of the forest vegetation simulation (FFE-FVS), photo series, planar intercept transects and table values (Tables) from van Wagtendonk \& Moore (2010).

\begin{tabular}{|c|c|c|c|c|c|c|c|c|}
\hline $\begin{array}{l}\text { Forest type and } \\
\text { method }\end{array}$ & 1-hr mg.ha-1 & 1-hr mg.ha-1 & 10-hr mg.ha-1 & 10-hr mg.ha ${ }^{-1}$ & 100-hr mg.ha ${ }^{-1}$ & $100-h_{r} m g \cdot h a^{-1}$ & Total 1-, 10-, 100-hr & $\begin{array}{l}\text { Total 1-, 10-, } \\
\text { 100-hr }\end{array}$ \\
\hline $\begin{array}{l}\text { Jeffrey pine } \\
(n=11)\end{array}$ & Ref. & Con. & Ref. & Con. & Ref. & Con. & Ref. & Con. \\
\hline FFE-FVS & $1.4(1.1-1.7)$ & $2.0(1.7-2.1)$ & $1.9(1.4-2.5)$ & $2.2(1.9-2.3)$ & $2.8(1.7-4.1)$ & $3.3(2.7-4.6)$ & $6.1(4.4-8.2)^{b}$ & $7.5(6.2-8.8)^{\mathrm{b}}$ \\
\hline Photo series & $0.2(0.2-0.2)$ & $0.4(0.0-0.4)$ & $2.5(1.6-3.4)$ & $1.3(1.1-2.2)$ & $1.4(0.9-1.8)$ & $2.5(1.8-4.5)$ & $4.2(2.7-5.4)$ & $4.2(3.6-6.7)$ \\
\hline Tables & $0.6(0.1-1.4)$ & & $3.3(2.1-5.8)$ & & $2.0(0.9-4.0)$ & & $6.0(3.2-10.3)$ & \\
\hline \multicolumn{9}{|l|}{$\begin{array}{l}\text { Mixed conifer } \\
(n=12)\end{array}$} \\
\hline FFE-FVS & $0.8(0.3-1.4)$ & $1.6(1.4-1.8)$ & $1.3(0.6-2.1)$ & $1.7(1.5-2.0)$ & $2.4(1.0-3.6)$ & $5.1(3.1-6.8)$ & $4.4(1.9-6.8)^{c}$ & $8.5(6.5-10.1)^{c}$ \\
\hline Photo series & $0.5(0.2-1.6)$ & $1.6(1.0-2.2)$ & $2.0(0.9-4.5)$ & $4.6(2.9-5.8)$ & $3.1(0.9-8.1)$ & $6.6(5.3-10.0)$ & $5.7(2.7-13.0)^{\mathrm{C}}$ & $12.9(9.2-17.8)^{\mathrm{C}}$ \\
\hline Planar intercept & & $0.9(0.3-1.5)$ & & $5.2(1.3-8.9)$ & & $6.1(2.5-14.5)$ & & $12.2(5.8-24.7)$ \\
\hline Tables & $1.6(0.5-3.0)$ & & $4.0(1.2-8.2)$ & & $3.2(1.0-6.5)$ & & $8.3(3.4-17.8)$ & \\
\hline \multicolumn{9}{|l|}{$\begin{array}{l}\text { Red fir } \\
\qquad(n=6)\end{array}$} \\
\hline FFE-FVS & $0.6(0.5-0.6)$ & $2.0(1.6-2.2)$ & $1.0(0.8-1.1)$ & $2.4(1.9-2.8)$ & $2.2(1.9-2.6)$ & $4.6(3.1-6.1)$ & $3.7(3.2-4.3)^{c}$ & $8.9(6.9-11.0)^{c}$ \\
\hline Photo series & $1.6(0.9-2.0)$ & $1.7(0.7-2.4)$ & $6.0(4.0-6.9)$ & $5.5(0.9-7.1)$ & $5.3(2.5-6.7)$ & $5.2(0.4-8.1)$ & $12.9(7.4-15.7)$ & $12.3(2.0-17.5)$ \\
\hline Tables & $3.4(2.0-3.9)$ & & $3.7(2.2-4.5)$ & & $1.6(1.0-1.8)$ & & $8.6(5.3-10.1)$ & \\
\hline \multicolumn{9}{|l|}{$\begin{array}{l}\text { Lodgepole pine } \\
\qquad(n=3)\end{array}$} \\
\hline FFE-FVS & $5.4(3.4-6.5)$ & $2.2(1.8-2.5)$ & $7.1(4.8-8.3)$ & $2.4(2.0-2.7)$ & $11.4(8.8-14.0)$ & $3.4(2.4-4.4)$ & $23.9(16.9-28.6)^{a}$ & $8.0(6.2-9.3)^{a}$ \\
\hline Photo series & $0.4(0.2-0.7)$ & $0.4(0.2-0.4)$ & $0.9(0.9-0.9)$ & $3.0(0.9-4.0)$ & $0.4(0.4-0.4)$ & $2.9(1.6-3.6)$ & $1.7(1.6-2.0)$ & $6.3(2.7-8.1)$ \\
\hline Tables & $2.5(1.5-3.2)$ & & $2.3(1.0-3.0)$ & & $1.1(0.4-1.4)$ & & $5.8(2.9-7.6)$ & \\
\hline
\end{tabular}

For the Average Total 1-, 10-, 100-hr columns, values in the same row with the same letter are significantly different (Kruskal-Wallis $\mathrm{H}$ test ${ }^{\mathrm{a}} \mathrm{P}<0.05$, $\left.{ }^{b} P<0.01,{ }^{c} P<0.001\right)$.

Table 2. Mean (range) canopy fuel characteristics for reference and contemporary forests in the Lake Tahoe Basin.

\begin{tabular}{|c|c|c|c|}
\hline Forest type & $\begin{array}{l}\text { Canopy bulk } \\
\text { density }\left(\mathrm{kg} \cdot \mathrm{m}^{-3}\right)\end{array}$ & $\begin{array}{l}\text { Canopy base } \\
\text { height }(\mathrm{m})\end{array}$ & Stand height (m) \\
\hline \multicolumn{4}{|l|}{ Jeffrey pine } \\
\hline Reference & $0.02(0.01-0.03)^{c}$ & $8.2(6.4-11.9)^{\mathrm{C}}$ & 30.1 (24.7-36.9) \\
\hline Contemporary & $0.07(0.04-0.10)^{c}$ & $0.6(0.3-0.9)^{c}$ & $31.9(28.0-36.6)$ \\
\hline \multicolumn{4}{|l|}{ Mixed conifer } \\
\hline Reference & $0.04(0.01-0.06)^{b}$ & $4.9(3.7-6.4)^{b}$ & $30.6(19.8-35.7)$ \\
\hline Contemporary & $0.09(0.03-0.18)^{b}$ & $0.5(0.3-1.2)^{b}$ & $31.8(23.2-39.6)$ \\
\hline \multicolumn{4}{|l|}{ Red fir } \\
\hline Reference & $0.05(0.04-0.07)^{a}$ & $6.6(6.1-7.6)^{c}$ & $34.5(31.1-36.3)^{c}$ \\
\hline Contemporary & $0.09(0.04-0.12)^{a}$ & $0.9(0.9-0.9)^{c}$ & $28.4(25.9-32.3)^{c}$ \\
\hline \multicolumn{4}{|l|}{ Lodgepole pine } \\
\hline Reference & $0.04(0.03-0.06)$ & $7.3(5.5-9.8)^{b}$ & $31.9(28.7-33.5)$ \\
\hline Contemporary & $0.08(0.03-0.11)$ & $0.8(0.6-0.9)^{b}$ & $27.8(26.8-29.0)$ \\
\hline
\end{tabular}

Values for reference and contemporary forests with the same letter were significantly different (Kruskal-Wallis $\mathrm{H}$ test, ${ }^{\mathrm{a}} P<0.05,{ }^{\mathrm{b}} P<0.01$, $\left.{ }^{\mathrm{c}} P<0.001\right)$.

MC experience mainly surface fires, except under 90th and 98th percentile conditions with FBM10 (Appendix S4). With FBM10 and more extreme weather, half or more of the MC reference plots experience passive crown fire. In contrast, contemporary JP and MC forests
Table 3. Upper 80th, 90th and 98th percentile weather conditions for weather and fuel moisture used for fire behaviour simulations for reference and contemporary forest conditions in the Lake Tahoe Basin, USA.

\begin{tabular}{llcc}
\hline Climate Variable & 80th percentile & 90th percentile & $\begin{array}{l}\text { 98th } \\
\text { percentile }\end{array}$ \\
& & & 30.6 \\
\hline Dry bulb temperature $\left({ }^{\circ} \mathrm{C}\right)$ & 27.8 & 28.9 & 5 \\
Low relative humidity (\%) & 11 & 8 & 100 \\
High relative humidity (\%) & 92 & 99 & 32 \\
Wind speed $\left(\mathrm{km} \cdot \mathrm{hr}^{-1}\right.$ ) & 19.4 & 25.9 & \\
Fuel moisture & & & 2 \\
1-hr (\%) & 3 & 2 & 3 \\
10-hr (\%) & 5 & 7 & 5 \\
100-hr (\%) & 9 & 73 & 70 \\
Live woody (\%) & 78 & 100 & 80 \\
Foliar moisture content (\%) & 100 & & \\
\hline
\end{tabular}

Data are from the Truckee, California, remote automated weather station May-October 1961-2006. Foliar moisture was assumed to be 100\% under both 80th and 90th percentile weather conditions (Scott \& Rhinehardt 2001; Finney 2004) and $80 \%$ under 98th percentile conditions weather conditions (Agee et al. 2002).

experience mainly passive crown or even active crown fire under more extreme fire weather.

There was less difference in potential contemporary and reference fire behaviour in RF and LP forests (Fig. 6a,b, Appendix S4). Only the torching index was lower in 

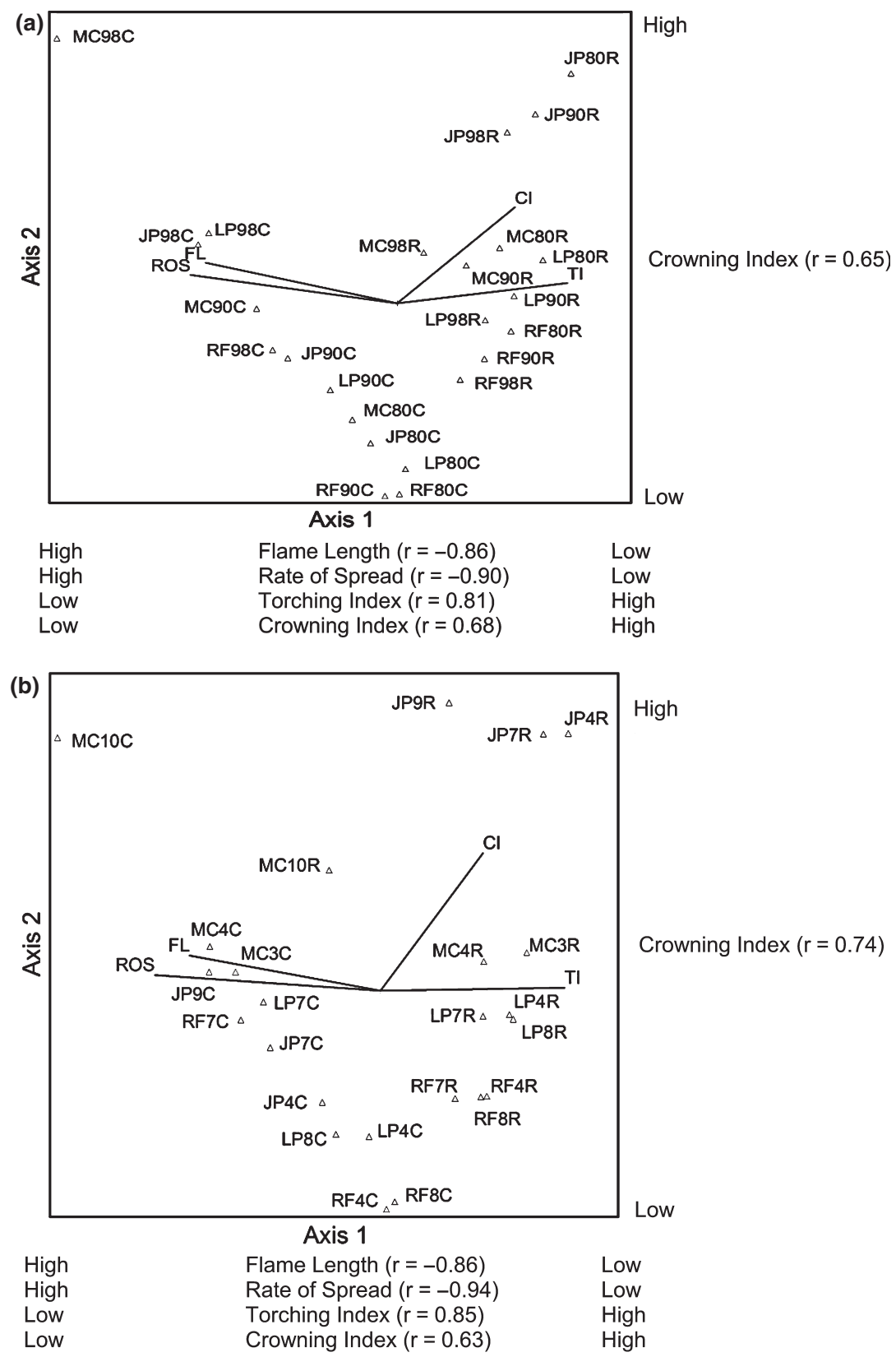

Fig. 6. Ordination of simulated fire behaviour for contemporary (C) and reference (R) forest types for average fuel conditions with variable weather (a) and average weather conditions with variable fuels (b) in the Lake Tahoe Basin, USA. Lines radiating from the centroid show correlation vectors of fire behaviour variables with ordination axes. All correlation vectors have $r^{2}$ values $>0.6$, and vector length represents strength of the correlation. The fire behaviour variables are flame length (FL), rate of spread (ROS), crowning index (CI) and torching index (TI); forest types are Jeffrey pine (JP), mixed conifer $(\mathrm{MC})$, red fir $(\mathrm{RF})$ and lodgepole pine $(\mathrm{LP})$. Significant $(P<0.01)$ Pearson correlation coefficients of variables with axis 1 and 2 scores are given in parenthesis. See $\mathrm{S} 4$ for additional fire behaviour simulation results for each weather and fuel scenario for reference and contemporary forests.

contemporary than reference forests. Rate of spread, and flame length, were only higher in contemporary than reference RF for TL7 under the most extreme weather conditions. This was also the case for flame length in LP forests.
Predicted fire types for RF and LP reference and contemporary forests were surface, except with TL7 under extreme weather conditions, when plots experienced passive and active crown fire (Appendix S4). 


\section{Discussion}

\section{Reference and contemporary forest structure}

Our reconstruction of reference forest conditions provides quantitative estimates of forest structure in the LTB before logging and disruption of fire regimes in the 1870s. The accuracy of the estimates, however, is limited by the forest reconstruction method. Reconstruction methods based on dendroecology depend on woody material, which is prone to removal by decay, logging or fire, which can eliminate evidence needed to reconstruct the forest (Fritts $\delta$ Swetnam 1989). Resistance to decay also varies by tree size and species, and in California forests, fir trees (Abies spp.) decay faster than associated pines (Pinus spp.) and small trees decay faster than large ones (Kimmey 1955; Harmon et al. 1987). Consequently, density, basal area and tree size estimates may be more reliable for pines than fir and for larger than smaller diameter trees. Certainly, death and complete decomposition of smaller diameter trees and stumps since 1873 would lead to an underestimate of forest density, but basal area estimates for larger trees would be less affected (Fulé et al. 1997; North et al. 2007; Scholl \& Taylor 2010). The earliest death date estimate for trees in our stands was 1929 for pines and 1935 for fir. This suggests that trees that died between 1873 and ca. 1930 may be unaccounted for in our reconstruction because of complete decomposition. Wood consumption by an unrecorded fire may also have eliminated evidence of the historic forest. Forest conditions were reconstructed to the year 1873 because it was the year of the last known fire in most plots on both the east and west shore (Taylor 2004; Beaty \& Taylor 2007).

Despite limitations of the forest reconstruction method, forest density and basal area estimates using this approach are similar to early forest survey estimates in dry ponderosa pine (Pinus ponderosa) forests in Arizona (Fulé et al. 1997; Huffman et al. 2001) and MC forests in Yosemite National Park (YNP; Scholl \& Taylor 2010; Collins et al. 2011). Reconstructed MC basal area and density in YNP in 1899 were statistically similar to 1911 forest survey basal area and density for the same location. This suggests reconstruction estimates from uncut forests are reliable. There are no similar comparisons of forest survey data with old cut stump estimates of basal area or density. Thus, estimates of forest density, basal area, tree diameter in JP, RF and LP forests are more uncertain than for MC forests, particularly for small-diameter stems that are difficult to identify using dendroecological methods (North et al. 2007). Nevertheless, reconstructed forest characteristics for 1873 are consistent with forest characteristics evident in 19th and early 20th century photographs and documents describing forest conditions with minimal impact from Anglo-American land use. These historic records suggest that reference forests were dominated by large-diameter trees and they were more open, particularly JP and MC forests, than contemporary forests (Strong 1984; Manley et al. 2000; Gruell 2001; Barbour et al. 2002; Taylor 2004; van de Water \& North 2010).

Our estimates of reconstructed reference conditions in the LTB are broadly similar to other estimates of 19th century forest characteristics. Reference MC forests had an average density of 132 trees.ha ${ }^{-1}$ and basal area of $29.4 \mathrm{~m}^{2} \cdot \mathrm{ha}^{-1}$, with stems relatively evenly distributed across size classes. These values are similar to reconstructions of density in MC forests in southwestern Colorado (142 trees·ha ${ }^{-1}$; Fulé et al. 2009), in YNP (160 trees.ha ${ }^{-1}$; Scholl \& Taylor 2010) and riparian and upland MC and JP forests in the northern Sierra Nevada (204 trees.ha ${ }^{-1}$; van de Water \& North 2010), but they are higher than reconstructed density for MC forests in the Teakettle Experimental Forest (67 trees.ha ${ }^{-1}$; North et al. 2007). Reference conditions in the LTB can also be compared to similar forests in the San Pedro Martir (SPM) in northern Mexico that have not experienced a long period of fire exclusion. In the SPM, MC stands have an average density and basal area of 110-141 trees $\cdot \mathrm{ha}^{-1}$ and 19-29.8 $\mathrm{m}^{2} \cdot \mathrm{ha}^{-1}$ (Minnich et al. 2000; Barbour et al. 2002; Stephens \& Gill 2005), respectively, similar to reconstructed values for the LTB. For JP in the LTB, average reconstructed values for density and basal area were 68 trees.ha ${ }^{-1}$ and $25.5 \mathrm{~m}^{2} \cdot \mathrm{ha}^{-1}$, respectively, similar to values for stems $>40 \mathrm{~cm} \mathrm{DBH}$ in remnant stands $(n=7)$ of old-growth JP in the LTB (mean density $=63$ trees $\cdot \mathrm{ha}^{-1}$, mean basal area $=27 \mathrm{~m}^{2} \cdot \mathrm{ha}^{-1}$; Barbour et al. 2002). Our reconstructed value for red fir density (162 trees.ha ${ }^{-1}$ ) was higher than for old-growth RF stands in the LTB (mean $=107$ trees $\cdot \mathrm{ha}^{-1} ; n=14$ ) but basal areas were similar $\left(55.8 \mathrm{~m}^{2} \cdot \mathrm{ha}^{-1}\right.$ vs $53 \mathrm{~m}^{2} \cdot \mathrm{ha}^{-1}$; Barbour et al. 2002).

Comparisons of reference and contemporary forest characteristics provide insight on how logging disturbance and fire exclusion shape current forest structure. Fire was eliminated from unlogged MC stands in 1873 and they now have three-fold more trees and twofold more basal area than the reference forest. These increases are mainly caused by the increase in shade-tolerant and fire-intolerant white fir that established after fire exclusion (Beaty $\delta$ Taylor 2007). The shift from a mixed pine-fir forest to one dominated by shade-tolerant species is part of a widespread shift in forest composition related to fire exclusion throughout California and the American Southwest (Minnich et al. 1995; Taylor 2000; Taylor \& Skinner 2003; Mast \& Wolf 2004; Scholl \& Taylor 2010; van de Water \& North 2010). JP forests experienced the most change due to abundant post-logging tree establishment without subsequent thinning by surface fire. Before 1873, JP forests had a regime of frequent surface fire that was patchy and low 
enough in severity to permit survival of some fire-intolerant trees (i.e. white fir) to a fire-resistant size (Taylor 2004). Contemporary JP forests now have five-fold more trees and double the basal area than the reference forest. Reference RF forests burn much less frequently than JP or MC forests (Taylor 2000; Taylor \& Beaty 2005; Scholl \& Taylor 2006; Beaty $\&$ Taylor 2007), and logging has probably been more important than fire exclusion for RF forest change (Taylor 2004). Contemporary RF forests were denser, and lodgepole pine is the dominant species. Before logging, lodgepole pine was only a minor component of RF stands. Severe logging of RF forests favoured abundant post-logging establishment of lodgepole pine, shifting RF forest composition towards lodgepole pine. These mixed forests are now poised to be replaced by red fir and western white pine saplings that are present in the understorey (Taylor 2004). Severe logging in LP forests also promoted abundant establishment of lodgepole pine, and contemporary LP forests, on average, were denser than other forest types in our sample. The contemporary LP forests size class distribution suggests that lodgepole pine is self-replacing on these sites (Parker 1986, 1993).

\section{Reference and contemporary fire behaviour}

Our surface and canopy fuels values for LTB reference forests represent a quantitative estimate of fuel conditions for forests with an intact fire regime. The fuel estimates, of course, are also influenced by the limitations of the dendroecological method. Surface fuel estimates derived from FFE-FVS or the Tables Method would be lower for a reconstructed forest with missing trees, and this could influence simulated potential fire behaviour. However, we only used the surface fuel estimates to identify standard fuel models (i.e. Anderson 1982; Scott \& Burgan 2005), which were then used to simulate potential fire behaviour. Fulé et al. 2004 and Brown et al. 2008 used a similar approach to estimate surface fuel loads for simulating fire behaviour in reference period ponderosa pine (Pinus ponderosa Dougl.) forests in Arizona and South Dakota, respectively. Jeffrey pine is morphologically very similar to ponderosa pine, and Jeffrey pine and ponderosa pine forests in California are structurally similar, but Jeffrey pine forests occupy more xeric high-elevation sites (Barbour \& Minnich 2000). Estimated reference period surface fuel models for ponderosa pine forests in Arizona (FBM9, FBM10) were comprised of leaf litter (Fulé et al. 2004) and on the high end of our bracketed estimates for surface fuels in reference JP and MC forests in the LTB, which are both dominated by Jeffrey pine. In contrast, surface fuels in reference ponderosa pine forests in South Dakota were thought to be primarily composed of forbs and grasses (model 2, Anderson 1982; Brown et al. 2008). We identified a range of standard fuel models for each type of reference and contemporary forest in the LTB. Presumably, the range of potential fire behaviour using a set of standard fuel models includes the expected behaviour with the reference fuel load estimates. Potential crown fire behaviour would also be influenced by missing small-diameter stems in a forest reconstruction. Potential for torching and the transition of surface to passive or active crown fire is influenced by the height and density of foliage ( $\mathrm{CBH}$ and $\mathrm{CBD}$ ) in the lower canopy (Agee \& Skinner 2005; Keane et al. 2005). Comparison of CBD estimates derived from different methods should be compared on a relative basis (Fulé et al. 2004). CBD in contemporary JP and MC forests in the LTB was 2.2-3.5-fold higher than for reference forests, which is similar to the 2.0-2.5-fold increase identified for contemporary ponderosa pine forests in Arizona and South Dakota (Fulé et al. 2004; Brown et al. 2008).

Although there are uncertainties in estimating fuel characteristics based on dendroecology, fire behaviour modelling demonstrates that logging and/or fire suppression have increased fuels and fire hazard in contemporary JP and MC forests. Higher flame lengths, higher rates of spread and lower torching indices compared to the reference all indicate the potential for more severe fire. Furthermore, potential fire type shifts from mainly surface to mainly passive crown fire under all simulated weather conditions. The fire type shift is driven by the lower $\mathrm{CBH}$ and higher $\mathrm{CBD}$ caused by increased forest density, which facilitates transition of surface fire into the canopy (Agee \& Skinner 2005). Similar shifts to more extreme fire behaviour including the probability of crown fire were also identified by Fulé et al. (2004) and Brown et al. (2008) in their comparisons of contemporary and reference ponderosa pine forests. In contrast, changes in RF and LP forest structure and fuels caused by logging and fire suppression reduced wind speeds for crowning and torching indices, but flame length and rate of spread only exceeded those for reference forests when weather was extreme and fuels loads were high. Surface fire was the most frequent fire type in RF and LP reference and contemporary forests, except when fuel loads were high and weather was extreme. This suggests there has been less change in potential fire behaviour since logging and fire exclusion in RF and LP than in lower elevation JP and MC forests. The severity of recent wildfires in the LTB supports an interpretation of high potential for severe fire in contemporary forests. More than half of the area burned in JP and MC forests in the 1250-ha Angora Fire in 2007 burned at high severity (Safford et al. 2009). 


\section{Management considerations}

Reference forest characteristics for fire-prone ecosystems are a useful starting point for management plans aimed at restoring highly altered forests to a fire resilient condition (White \& Walker 1997; Agee \& Skinner 2005; Reinhardt et al. 2008). For the LTB, the consensus of resource management agencies and citizen stakeholders is to shift contemporary forest structure towards structures typical of the pre-Anglo-American forests that had an intact fire regime (i.e. Christopherson et al. 1996). Our quantitative reconstruction of pre-Anglo-American forest structure provides a range of estimates of stand density, basal area, size class structure, surface and canopy fuels, and potential fire behaviour that can support the restoration planning process. These estimates, however, should be used judiciously and integrated with other ecological knowledge in developing specific restoration plans. Our reference data come from a limited portion of the landscape where uncut, old-growth forests were still present and cut stumps were well preserved because of site conditions and lack of fire. Reference forest characteristics derived from other sites or other parts of the landscape may deviate from those in our sample. For example, there is evidence of pre-Anglo-American high-severity fire in the MC zone in the form of large stands (>20 ha) of firedependent montane chaparral (Nagel \& Taylor 2005; Beaty $\&$ Taylor 2008). Chaparral stands are now converting to forest because they have not burned in the last 120 yrs. Our fire modelling results also suggest that severe fire effects in the form of passive crown fire were possible in the pre-Anglo-American forest landscape. However, our intensive stand-level reconstruction method could not quantify the extent and location of chaparral or other high-severity fire effects in the preAnglo-American landscape. Clearly, from a management planning perspective, the restored landscape should include some areas of montane chaparral and forest recovering from high-severity fire.

Each contemporary forest type in the LTB was different than the reference but in different ways, and management plans should be guided by this variability. Our data indicate that contemporary JP and MC forests deviate the most from the reference. Restoration objectives for these forests should emphasize density and basal area reduction, particularly for small-diameter stems and shade-tolerant species in MC forests. Periodic fire or other fuel treatments will be needed to reduce and maintain lower surface loads, and treatments will need to maintain a high $\mathrm{CBH}$ and lower CBD to ensure a low probability of torching and crown fire spread. Restoration objectives for RF forests should shift species composition and reduce basal area by selectively thinning smaller diameter lodgepole pine. For LP forests, restoration objectives should include reduction of density and basal area of smaller-diameter stems. Fire or other surface fuel treatments should also be applied to RF and LP forests, but at longer intervals, since fire frequency in these forests is lower than in JP and MC forests (Taylor 2004; Scholl \& Taylor 2006; Beaty \& Taylor 2007; Caprio 2008).

\section{Acknowledgements}

This research was completed with the assistance of many individuals. We thank Tamara Sasaki and Dave Fournier for logistical support, and Derek Furry, Melissa Harkavy, Warren Reed and Ben Wharton for field assistance. Hugh Safford provided helpful comments on an earlier draft of this paper. This project was funded by a SNMPLA Grant through the USDA Forest Service Pacific Southwest Research Station.

\section{References}

Agee, J.K., Wright, C.S., Williamson, N. \& Huff, M.H. 2002. Foliar moisture content of Pacific Nortwest vegetation and its relation to wildland fire behaviour. Forest Ecology and Managmeent 167: 57-66.

Agee, J.K. \& Skinner, C.N. 2005. Basic principles of forest fuel reduction treatments. Forest Ecology and Management 211: 83-96.

Anderson, H.E. 1982. Aids to determining fuel models for estimating fire behavior. Intermountain Research Station, General Technical Report INT-122. United States Department of Agriculture, Washington, DC, US.

Arno, S.F. \& Fiedler, C.E. 2005. Mimicking nature's fire: restoring fire prone forests in the west. Island Press, Washington, DC, US.

Barbour, M.G. \& Minnich, R.A. 2000. California upland forests and woodlands. In: Barbour, M.G. \& Billings, W.D. (eds.) North American terrestrial vegetation, pp. 131-164. Cambridge University Press, New York, NY, US.

Barbour, M., Kelley, E., Maloney, P., Rizzo, D., Royce, E. \& Fites-Kaufmann, J. 2002. Present and past old-growth forests of the Lake Tahoe Basin, Sierra Nevada, US. Journal of Vegetation Science 13: 461-472.

Beaty, R.M. \& Taylor, A.H. 2007. Fire disturbance and forest structure in old-growth mixed conifer forests in the northern Sierra Nevada, California. Journal of Vegetation Science 18: 879-890.

Beaty, R.M. \& Taylor, A.H. 2008. Fire history and the structure and dynamics of a mixed conifer forest landscape in the northern Sierra Nevada, Lake Tahoe Basin, California, USA. Forest Ecology and Management 255: 707719.

Beesley, D. 1996. Reconstructing the landscape: an environmental history, 1820-1960. In: Erman, D.C. (ed.) Sierra Nevada 
ecosystem project - final report to congress, Vol. II: assessment and scientific basis for management options, pp. 3-24. University of California, Centers for Water and Wildland Resources, Davis, CA, US.

Blonski, K.S. \& Schramel, J.L. 1981. Photo series for quantifying natural forest residues: southern Cascades and northern Sierra Nevada. Pacific Southwest Research Station, General Technical Report PSW-5. United States Department of Agriculture, Washington, DC, US.

Brown, J.K. 1974. Handbook for inventorying downed woody material. Intermountain Research Station, General Technical Report INT-16. United States Department of Agriculture, Washington, DC, US.

Brown, T.J., Hall, B.L. \& Westerling, A.L. 2004. The impact of twenty-first century climate change on wildland fire danger in the western United States: an applications perspective. Climatic Change 62: 365-388.

Brown, P.M., Wienk, C.L. \& Symstad, A.J. 2008. Fire and forest history at Mount Rushmore. Ecological Applications 18: 19841999.

Burgan, R.E. \& Rothermel, R.C. 1984. BEHAVE: fire behavior predition and fuel modeling system - FUEL subsystem. Intermountain Research Station, General Technical Report INT-167. United States Department of Agriculture, Washington, DC, US.

Caprio, A.C. 2008. Reconstructing fire history of lodgepole pine on Chagoopa Plateau, Sequoia National Park, California In: Nanog, M.G. (ed.) Managing fire and fuels in the remaining wildlands and open spaces of the southwestern United States. pp. 255261. Pacific Southwest Research Station General Technical Report PSW-189, United States Department of Agriculture, Washington, DC, US.

Christopherson, J., Lewis, S.R. \& Havercamp, M. 1996. Lake Tahoe's forest health consensus group. Journal of Forestry 94 : $10-12$.

Collins, B.M., Everett, R.G. \& Stephens, S.L. 2011 . Impacts of fire exclusion and recent managed fire on forest structure in old growth Sierra Nevada mixed-conifer forests. Ecosphere 2: $1-14$.

Elliot-Fisk, D. 1996. Lake Tahoe case study. In: Erman, D.C. (ed.) Sierra Nevada ecosystem project - final report to congress, Vol. II: assessment and scientific basis for management options, pp. 217268. University of California, Centers for Water and Wildland Resources, Davis, CA, US.

Finney, M.A. 2004. FARSITE: fire area simulator-model development and evaluation. Rocky Mountain Research Station Research Paper RMRS-4. United States Department of Agriculture, Washington, DC, US.

Franklin, J.F. \& Fites-Kaufmann, J.A. 1996. Assessment of latesuccessional forests of the Sierra Nevada. In: Erman, D.C. (ed.) Sierra Nevada ecosystem project: final report to congress, Vol. II, assessments and scientific basis for management options, pp. 627-662. University of California, Centers for Water and Wildland Resources, Davis, CA, US.
Fritts, H.C. \& Swetnam, T.W. 1989. Dendroecology: a tool for evaluating variations in past and present forest environments. Advances in Ecological Research 19: 111-188.

Fulé, P.Z., Covington, W.W. \& Moore, M.M. 1997. Determining reference conditions for ecosystem management of southwestern ponderosa pine forests. Ecological Applications 7: 895908.

Fulé, P.Z., Covington, W.W., Moore, M.M. \& Heinlein, T.A. 2002. Natural variability in forests of the Grand Canyon, USA. Journal of Biogeography 29: 31-47.

Fulé, P.Z., Crouse, J.E., Cocke, A.E., Moore, M.M. \& Covington, W.W. 2004. Changes in canopy fuels and potenital fire behavior 1880-2040: Grand Canyon, Arizona. Ecological Modelling 175: 231-248.

Fulé, P.Z., Korb, J.E. \& Wu, R. 2009. Changes in forest structure in a mixed conifer forest, Colorado, USA. Forest Ecology and Management 258: 1200-1210.

Graham, R., McCaffrey, S. \& Jain, T. 2004. Science basis for changing forest structure to modify wildfire behavior and severity. Rocky Mountain Research Station General Technical Report RMRS-GTR-120. United States Department of Agriculture, Washington, DC, US.

Gruell, G. 2001. Fire in Sierra Nevada forests: a photographic interpretation of ecological change since 1849. Mountain Press, Missoula, MT, US.

Harmon, M.E., Cromack, K. Jr \& Smith, B.G. 1987. Coarse woody debris in mixed-conifer forests, Sequoia National Park, California. Canadian Journal of Forest Research 17: 12651272.

Hickman, J.C. 1993. The Jepson manual: higher plants of California. University of California Press, Berkeley, CA, US.

Huffman, D.W., Moore, M.M., Covington, W.W., Crouse, J.E. \& Fulé, P.Z. 2001. Ponderosa pine forest reconstruction: comparisons with historical data. In: Vance, R.K., Edminster, C.B., Covington, W.W. \& Blake, J.A.(eds.). (comps.). Ponderosa pine ecosystems restoration and conservation: steps toward stewardship. Rocky Mountain Research Station Proceedings RMRS-22. United States Department of Agriculture, 3-8. Washington, DC, US.

Hymanson, Z.P. \& Collopy, M.W. 2010. An integrated science plan for the Lake Tahoe Basin: conceptual framework and research strategies. Pacific Southwest Research Station General Technical Report PSW-GTR-226. United States Department of Agriculture, Washington, DC, US.

Keane, R.E., Reinhardt, E.D., Scott, J., Gray, K. \& Reardon, J. 2005. Estimating forest canopy bulk density using six indirect methods. Canadian Journal of Forest Research 35: 724-739.

Kimmey, J.W. 1955. Rate of deterioration of fire-killed timber in California. Circular 962. United States Department of Agriculture, Washington, DC, US.

Lindström, S. 2000. A contextual overview of human land use and environmental conditions. In: Murphy, D.D. \& Knopp, C.M. (eds.) Lake Tahoe Watershed assessment: Volume I, pp. 23127. Pacific Southwest Research Station General Technical 
Report PSW-175. United States Department of Agriculture, Washington, DC, US.

Manley, P.N., Fites-Kaufman, J.A., Barbour, M.G., Schlesinger, M.D. \& Rizzo, D.M. 2000. Biological integrity. In: Murphy, D.D. \& Knopp, C.M. (eds.) Lake Tahoe Watershed assessment, Vol. I, pp. 403-597. Pacific Southwest Research Station General Technical Report PSW-175. United States Department of Agriculture, Washington, DC, US.

Maser, C., Anderson, R.G., Cromack, K.J., Williams, J.T. \& Martin, R.E. 1979. Dead and down woody material. In: Thomas, J.W. (ed.) Wildlife habitats in managed forests - the Blue Mountains of Oregon and Washington, pp. 78-95. Pacific Northwest Research Station General Technical Report PNW-118. United States Department of Agriculture, Washington, DC, US.

Mast, J.N. \& Wolf, J.J. 2004. Ecotonal changes and altered tree spatial patterns in lower mixed-conifer forests. Landscape Ecology 19: 167-180.

McCune, B., Grace, J.B. \& Urban, D.L. 2002. Analysis of ecological communities. MJM Software, Gold Beach, OR, US.

McKelvey, K.S. \& Johnston, J.D. 1992. Historical perspectives on forests of the Sierra Nevada and the Transverse Ranges of southern California: forest conditions at the turn of the century. In: Verner, J., Mckelvey, K.S., Noon, B.R., Gutierrez, R.J., Gould, G.I. \& Beck, T.W. (eds.) The California Spotted Owl: a technical assessment of its current conditions, pp. 225-246. Pacific Southwest Research Station General Technical Report PSW-GTR-133. United States Department of Agriculture, Washington, DC, US.

Miller, J.D., Safford, H.D., Crimmins, M. \& Thode, A.E. 2009. Quantitative evidence for increasing forest fire severity in the Sierra Nevada and southern Cascade Mountains, California and Nevada, U.S.A. Ecosystems 12: 16-32.

Miller, J.D., Skinner, C.N., Safford, H.D., Knapp, E.E. \& Ramirez, C.M. 2012. Trends and causes of severity, size, and number of fires in northwestern California, USA. Ecological Applications 22: 184-203.

Minnich, R.A., Barbour, M.G., Burk, J.H. \& Fernau, R.F. 1995. Sixty years of change in Californian conifer forests of the San Bernardino Mountains. Conservation Biology 9: 902-914.

Minnich, R.A., Barbour, M.G., Burk, J.H. \& Fernau, R.F. 2000. Californian mixed-conifer forests under unmanaged fire regimes in the Sierra San Pedro Martir, Baja California, Mexico. Journal of Biogeography 27: 105-129.

Morgan, P., Aplet, G.H., Haufler, J.B., Humphries, H.C., Moore, M.M. \& Wilson, W.D. 1994. Historical range of variability. Journal of Sustainable Forestry 2: 87-111.

Nagel, T.A. \& Taylor, A.H. 2005. Fire and persistence of montane chaparral in mixed conifer forest landscapes in the northern Sierra Nevada, Lake Tahoe Basin, California, USA. Journal of the Torrey Botanical Society 132: 442-457.

North, M., Innes, J. \& Zald, H. 2007. Comparison of thinning and prescribed fire restoration treatments to Sierran mixedconifer historic conditions. Canadian Journal of Forest Research 37: $331-342$.
Noss, R.F., Franklin, J.F., Baker, W.L., Schoennagel, T. \& Moyle, P.B. 2006. Managing fire-prone forests in the western United States. Frontiers in Ecology and the Environment 4: 481-487.

Parker, A.J. 1986. Environmental and historical factors affecting red and white fir regeneration in ecotonal forests. Forest Science 32: 339-347.

Parker, A.J. 1993. Structural variation and dynamics of lodgepole pine forests in Lassen Volcanic National Park, California. Annals of the Association of American Geographers 83: 613-629.

Reinhardt, E.D. \& Crookston, N.L. 2003. The fire and fuels extension to the forest vegetation simulator. Rocky Mountain Research Station General Technical Report RMRS-GRT-116. United States Department of Agriculture, Washington, DC, US.

Reinhardt, E.D., Keane, R.E., Calkin, D.E. \& Cohen, J.D. 2008. Objectives and considerations for wildland fuel treatment in forested ecosystems of the interior western United States. Forest Ecology and Management 256: 1997-2006.

Rogers, J.J. 1984. ECOSIM: a system for projecting multiresource outputs under alternative forest management regimes. Rocky Mountain Research Station Administrative Report, Fort Collins, CO, US.

Rothermel, R.C. \& Rinehart, G.C. 1983. Field procedures for verification and adjustment of fire behavior predictions. Intermountain Research Station General Technical Report INT-142. United States Department of Agriculture, Washington, DC, US.

Safford, H.D., Schmidt, D.A. \& Carlson, C.H. 2009. Effects of fuel treatments on fire severity in an area of wildland-urban interface, Angora Fire, Lake Tahoe Basin, California. Forest Ecology and Management 258: 773-787.

Scholl, A.E. \& Taylor, A.H. 2006. Regeneration patterns in oldgrowth red fir - western white pine forests in the northern Sierra Nevada, Lake Tahoe, USA. Forest Ecology and Management 235: 143-154.

Scholl, A.E. \& Taylor, A.H. 2010. Fire regimes, forest change, and self-organization in an old-growth mixed-conifer forest, Yosemite National Park, USA. Ecological Applications 20: 362380.

Scott, J.H. \& Reinhardt, E.D. 2001. Assessing crown fire potential by linking models of surface and crown fire behavior. Rocky Mountain Research Station Research Paper RMRS-29. United States Department of Agriculture, Washington, DC, US.

Scott, J.H. \& Burgan, R.E. 2005. Standard fire behavior fuel models: a comprehensive set for use with Rothermel's surface fire spread model. Rocky Mountain Research Station General Technical Report RMRS-GTR-153. United States Department of Agriculture, Washington, DC, US.

Skinner, C.N. \& Chang, C. 1996. Fire regimes, past and present. In: Erman, D.C. (ed.) Sierra Nevada ecosystem project - final report to congress, Vol. II: assessment and scientific basis for management options, pp. 1041-1069. University of California, Centers for Water and Wildland Resources, Davis, CA, US.

Sokal, R. \& Rohlf, F. 1995. Biometry: the principles and practice of statistics in biological research. Freeman \& Co., New York, NY, US. 
Stephens, S.L. \& Gill, S.J. 2005. Forest structure and mortality in an old-growth Jeffrey pine-mixed conifer forest in northwestern Mexico. Forest Ecology and Management 205: 15-28.

Strong, D.H. 1984. Tahoe: an environmental history. University of Nebraska Press, Lincoln, NE, US.

Taylor, A.H. 2000. Fire regimes and forest changes in mid and upper montane forests of the southern Cascades, Lassen Volcanic National Park, California, USA. Journal of Biogeography 27: 87-104.

Taylor, A.H. 2004. Identifying forest reference conditions on early cut-over lands, Lake Tahoe Basin, USA. Ecological Applications 14: 1903-1920.

Taylor, A.H. \& Beaty, R.M. 2005. Climatic influences on fire regimes in the northern Sierra Nevada mountains, Lake Tahoe Basin, Nevada, USA. Journal of Biogeography 32: 425438.

Taylor, A.H. \& Skinner, C.N. 2003. Spatial patterns and controls on historical fire regimes and forest structure in the Klamath Mountains. Ecological Applications 13: 704-719.

Thomas, J.W. 1979. Wildlife habitats in managed forests: the Blue Mountains of Oregon and Washington. Handbook 553. United States Department of Agriculture, Washington, DC, US.

van Wagtendonk, J.W. \& Fites-Kaufman, J.A. 2006. Sierra Nevada bioregion. In: Sugihara, N.G., van Wagtendonk, J.W., Fites-Kaufmann, J.A., Shaffer, K.E. \& Thode, A.E. (eds.) Fire in California's ecosystems, pp. 264-294. University of California Press, Berkeley, CA, US. van Wagtendonk, J.W. \& Moore, P.E. 2010. Fuel deposition rates of montane and subalpine conifers in the central Sierra Nevada, California, USA. Forest Ecology and Management 259: 2122-2132.

van de Water, K. \& North, M. 2010. Fire history of coniferous riparian forests in the Sierra Nevada. Forest Ecology and Management 260: 384-395.

White, P.S. \& Walker, J.L. 1997. Approximating nature's variation: selecting and using reference information in restoration ecology. Restoration Ecology 5: 338-349.

\section{Supporting Information}

Additional supporting information may be found in the online version of this article:

Appendix S1. Site characteristics of sampled forest stands.

Appendix S2. Sensitivity analysis of decomposition class on reconstructed stand characteristics.

Appendix S3. Characteristics of contemporary and reference forest characteristics.

Appendix S4. Simulated fire behaviour in contemporary and reference forests. 


\section{Appendices}

S1. Site characteristics of reference and contemporary forest stands in the Lake Tahoe Basin, USA. ${ }^{\text {a}}$ Slope aspects are north $\left(\mathrm{N}=315-44^{\circ}\right)$, east $\left(\mathrm{E}=45-134^{\circ}\right)$, south $\left(\mathrm{S}=135-224^{\circ}\right)$, west $\left(\mathrm{W}=225-314^{\circ}\right) .{ }^{\mathrm{b}} \mathrm{TRMI}$ is a topographically based site moisture index that ranges from 0 (xeric) to 60 (mesic) (Parker, 1982). ${ }^{\text {CN }}$ Number of plots with a given characteristic.

\begin{tabular}{|c|c|c|c|c|c|c|c|c|c|c|c|}
\hline \multirow[b]{2}{*}{ Forest type } & \multirow{2}{*}{$\begin{array}{l}\text { No. } \\
\text { Plots }^{c}\end{array}$} & \multirow[b]{2}{*}{$\mathbf{N}$} & \multicolumn{3}{|c|}{ Aspect $^{\mathrm{a}}$} & \multirow{2}{*}{$\begin{array}{l}\text { Slope }\left(^{\circ}\right) \\
\text { Mean }\end{array}$} & \multirow[b]{2}{*}{ Range } & \multicolumn{2}{|c|}{ Elevation (m) } & \multicolumn{2}{|l|}{ TRMI $^{\mathrm{b}}$} \\
\hline & & & $\mathbf{E}$ & W & $\mathbf{S}$ & & & Mean & Range & Mean & Range \\
\hline Jeffrey pine & 11 & 0 & 1 & 4 & 6 & 13 & $2-19$ & 2237 & $1980-2315$ & 23 & $7-39$ \\
\hline Mixed conifer & 12 & 4 & 1 & 1 & 6 & 13 & $1-32$ & 2034 & $1948-2109$ & 33 & $14-54$ \\
\hline Red fir & 6 & 2 & 0 & 3 & 1 & 8 & $4-19$ & 2546 & $2485-2610$ & 30 & $18-51$ \\
\hline Lodgepole pine & 3 & 0 & 1 & 0 & 2 & 3 & $2-5$ & 2535 & $2370-2620$ & 30 & $17-41$ \\
\hline
\end{tabular}


S2. Mean $( \pm$ SE) density, basal area, quadratic mean diameter, and number of dead trees assigned a death date in the mid to late $20^{\text {th }}$ century (with estimated establishment dates before 1873) for the reference forest for three decomposition condition models $\left(25^{\text {th }}\right.$ percentile, $50^{\text {th }}$ percentile, $75^{\text {th }}$ percentile). Values are for trees $>10 \mathrm{~cm}$ dbh and did not differ among decomposition classes $(p>0.05)$.

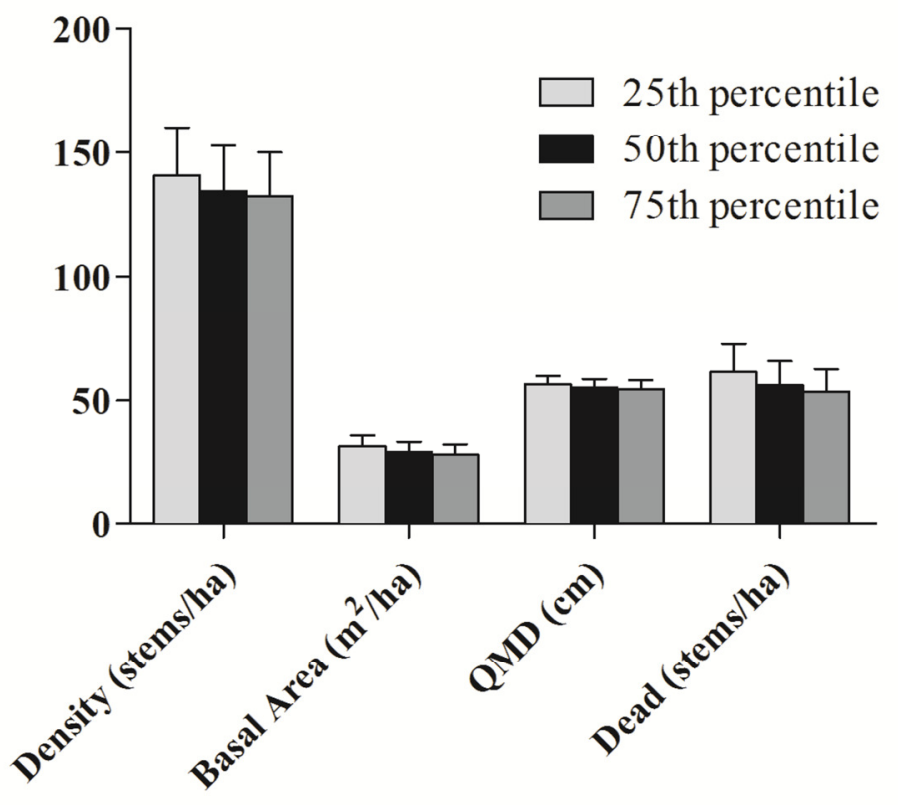


S3. Structural characteristics of contemporary and reference forests Jeffrey pine, mixed conifer, red fir, and lodgepole pine forests in the Lake Tahoe Basin, USA. Species acronyms are ABCO, Abies concolor; ABMA, A. magnifica; CADE, Calocedrus decurrens; PICO, Pinus contorta; PIJE, P. jeffreyii $;$ PILA, P. lambertiana; PIMO, P. monticola. $\mathrm{n}$ is the number of plots. Contemporary and reference value pairs in each row were compared with a Kruskal-Wallis H-test $(* \mathrm{P}<0.05)$.

\begin{tabular}{|c|c|c|c|c|c|c|c|c|c|c|}
\hline & & \multicolumn{3}{|c|}{ Density } & \multicolumn{3}{|c|}{ Basal Area } & \multicolumn{3}{|c|}{ Quadratic Mean Diameter } \\
\hline \multicolumn{2}{|c|}{ Jeffrey pine $(\mathrm{n}=11)$} & Mean & SD & Range & Mean & SD & Range & Mean & $\mathrm{SD}$ & Range \\
\hline \multirow[t]{2}{*}{$\mathrm{ABCO}$} & Contemporary & 38.0 & 21.60 & $28-70$ & 5.1 & 2.8 & $0.4-11$ & $45.4^{*}$ & 14.1 & $25.3-66.4$ \\
\hline & Reference & 13.0 & 9.70 & $0-32$ & 5.7 & 4.1 & $0-12$ & $76.3 *$ & 27.9 & $54.8-113$ \\
\hline \multirow[t]{2}{*}{ ABMA } & Contemporary & 8.0 & 19.10 & $0-68$ & 2.4 & 5.3 & $0-18.2$ & $43.7 *$ & 12.8 & $39.2-58.2$ \\
\hline & Reference & 1.0 & 2.80 & $0-10$ & 0.4 & 1.0 & $0-2.6$ & $75.5^{*}$ & 78.9 & $56.2-97.2$ \\
\hline \multirow[t]{2}{*}{ PIJE } & Contemporary & $297.0^{*}$ & 171.50 & $132-758$ & $19.4^{*}$ & 6.6 & $23.4-48.1$ & $38.7 *$ & 8.5 & $28.6-52.5$ \\
\hline & Reference & $55.0^{*}$ & 19.70 & $26-90$ & $38.9 *$ & 5.3 & $11.6-29.3$ & $68.0 *$ & 7.8 & $54-85.6$ \\
\hline \multirow[t]{2}{*}{ Total } & Contemporary & $343.0 *$ & 178.70 & $172-794$ & $46.4^{*}$ & 6.3 & $28.4-58.7$ & $39.4 *$ & 8.8 & $27.8-52.7$ \\
\hline & Reference & $68.0 *$ & 22.20 & $30-114$ & $25.5^{*}$ & 8.1 & 12.6-38.1 & $67.5^{*}$ & 8.1 & $54.7-85.3$ \\
\hline & & \multicolumn{3}{|c|}{ Density } & \multicolumn{3}{|c|}{ Basal Area } & \multicolumn{3}{|c|}{ Quadratic Mean Diameter } \\
\hline \multicolumn{2}{|c|}{ Mixed conifer $(n=12)$} & Mean & SD & Range & Mean & SD & Range & Mean & SD & Range \\
\hline \multirow[t]{2}{*}{$\mathrm{ABCO}$} & Contemporary & $292.9^{*}$ & 202 & $67.1-644$ & $26.8^{*}$ & 16.6 & $4.6-60$ & 35.4 & 8 & $25.3-48.7$ \\
\hline & Reference & $65.9^{*}$ & 46.5 & 14-144 & $8.0^{*}$ & 6.1 & $2.6-20$ & 44 & 11.9 & $24.3-66.2$ \\
\hline \multirow[t]{2}{*}{ ABMA } & Contemporary & 40.2 & 80.6 & $0-266$ & 5.4 & 9.8 & $0-27.5$ & 23.1 & 22.3 & $0-57.4$ \\
\hline & Reference & 11.6 & 18.5 & $0-56$ & 2.4 & 4.4 & $0-14.8$ & 21.6 & 24.7 & $0-58$ \\
\hline \multirow[t]{2}{*}{ CADE } & Contemporary & 12.8 & 28.1 & $0-90$ & 5.3 & 10.7 & $0-31.4$ & 19.4 & 35.4 & $0-88.9$ \\
\hline & Reference & 5.1 & 10.5 & $0-30$ & 3.5 & 6.9 & $0-18.6$ & 24.1 & 43.7 & $0-106.3$ \\
\hline \multirow[t]{2}{*}{ PICO } & Contemporary & 6.8 & 12.3 & $0-40$ & 0.5 & 0.7 & $0-1.9$ & 18.5 & 25.4 & $0-85.5$ \\
\hline & Reference & 0.3 & 0.7 & $0-2$ & 0.03 & 0.1 & $0-0.3$ & 5 & 13 & $0-43$ \\
\hline \multirow[t]{2}{*}{ PIJE } & Contemporary & 41.7 & 29.3 & $2-88$ & 15.6 & 11.6 & $0.1-43$ & 69.4 & 23.9 & $20.5-121.5$ \\
\hline & Reference & 43.9 & 25.2 & $12-104$ & 12.4 & 8.6 & $2.2-26$ & 58.1 & 11.4 & 41.6-81.2 \\
\hline
\end{tabular}




\begin{tabular}{|c|c|c|c|c|c|c|c|c|c|c|}
\hline \multirow[t]{2}{*}{ PILA } & Contemporary & 2.9 & 28.1 & $0-90$ & 2.3 & 4.9 & $0-16.3$ & 33.7 & 48.2 & $0-144.2$ \\
\hline & Reference & 2.9 & 4.5 & $0-14$ & 1.9 & 4.3 & $0-15$ & 32.7 & 47.3 & $0-123.7$ \\
\hline \multirow[t]{2}{*}{ PIMO } & Contemporary & 5.3 & 13.5 & $0-44$ & 1.3 & 3 & $0-7.9$ & 9.7 & 23 & $0-68.4$ \\
\hline & Reference & 2 & 4.7 & $0-14$ & 0.3 & 0.7 & $0-2$ & 7.3 & 17.3 & $0-50.1$ \\
\hline \multirow[t]{3}{*}{ Total } & Contemporary & $402.6^{*}$ & 205.9 & $127.1-734$ & $57.2 *$ & 26.2 & $24.4-105.8$ & 44.2 & 7.9 & $29.8-57.7$ \\
\hline & Reference & $131.6^{*}$ & 61.9 & 54-252 & $29.4 *$ & 14.4 & $8.7-54$ & 53 & 5.3 & 45.2-61.4 \\
\hline & & \multicolumn{3}{|c|}{ Density } & \multicolumn{3}{|c|}{ Basal Area } & \multicolumn{3}{|c|}{ Quadratic Mean Diameter } \\
\hline \multicolumn{2}{|c|}{ Red fir $(n=6)$} & Mean & SD & Range & Mean & SD & Range & Mean & SD & Range \\
\hline $\mathrm{ABCO}$ & $\begin{array}{l}\text { Contemporary } \\
\text { Reference }\end{array}$ & 1.00 & 1.70 & $0-4$ &, 0.1 & 0.10 & $0-0.2$ & 27.60 & & \\
\hline \multirow[t]{2}{*}{ ABMA } & Contemporary & $184.0^{*}$ & 142.0 & $14-328$ & 24.0 & 16.9 & $5.7-50$ & $42.1 *$ & 10.3 & $31.5-60.7$ \\
\hline & Reference & $94.0^{*}$ & 32.1 & $68-142$ & 40.0 & 9.3 & $27-53$ & $73.5^{*}$ & 8.1 & $62.3-80.8$ \\
\hline \multirow[t]{2}{*}{ PICO } & Contemporary & $274.0^{*}$ & 188.8 & $0-484$ & $17.9 *$ & 10.5 & $0-31.6$ & $28.3^{*}$ & 5.1 & $23.2-31.4$ \\
\hline & Reference & $14.0^{*}$ & 23.0 & $0-58$ & $0.3 *$ & 3.2 & $0-8.2$ & $33.8 *$ & 10.3 & $27.3-41.5$ \\
\hline PIJE & $\begin{array}{l}\text { Contemporary } \\
\text { Reference }\end{array}$ & 3.0 & 2.8 & $0-6$ & 0.1 & 0.1 & $0-0.3$ & 20.0 & 7.6 & $16.8-23.1$ \\
\hline \multirow[t]{2}{*}{ PIMO } & Contemporary & 71.0 & 52.4 & $14-176$ & $6.5^{*}$ & 5.1 & $0.8-13.3$ & $32.1 *$ & 8.3 & $21.8-41.5$ \\
\hline & Reference & 53.0 & 17.9 & $22-74$ & $15.5^{*}$ & 6.4 & $5.8-22.2$ & $63.9 *$ & 9.8 & 47.3 \\
\hline \multirow[t]{2}{*}{ Total } & Contemporary & $538.0^{*}$ & 259.1 & $214-842$ & 48.5 & 15.4 & $31.7-71.4$ & $33.1 *$ & 5.6 & $26.7-39.8$ \\
\hline & Reference & $162.0^{*}$ & 33.1 & $118-208$ & 55.8 & 9.3 & 40.9-67.8 & $64.9 *$ & 7.1 & $56.6-75.1$ \\
\hline & & \multicolumn{3}{|c|}{ Density } & \multicolumn{3}{|c|}{ Basal Area } & \multicolumn{3}{|c|}{ Quadratic Mean Diameter } \\
\hline \multicolumn{2}{|c|}{ Lodgepole pine $(\mathrm{n}=3)$} & Mean & SD & Range & Mean & SD & Range & Mean & SD & Range \\
\hline $\mathrm{ABCO}$ & $\begin{array}{l}\text { Contemporary } \\
\text { Reference }\end{array}$ & 1.0 & 1.2 & 0.20 & 0.4 & 0.5 & $0-1.0$ & 14.4 & & \\
\hline \multirow[t]{2}{*}{ ABMA } & Contemporary & 27.0 & 3.5 & $0-76$ & 6.4 & 11.1 & $0-19$ & 42.9 & 17.0 & $33.2-52.5$ \\
\hline & Reference & 12.0 & 17.3 & $0-32$ & 1.5 & 1.4 & $0-2.3$ & 59.5 & 44.2 & $33.9-52.5$ \\
\hline \multirow[t]{2}{*}{ PICO } & Contemporary & $583.0^{*}$ & 334.0 & $202-850$ & $40.3 *$ & 14.5 & $26-55.1$ & $29.4 *$ & 6.6 & $25.4-36.9$ \\
\hline & Reference & $171.0^{*}$ & 74.0 & $90-234$ & $55.6^{*}$ & 32.0 & $29.7-91.4$ & $62.4 *$ & 7.3 & $54.5-69.2$ \\
\hline
\end{tabular}




\begin{tabular}{llrrrrrrrrr} 
PIJE & Contemporary & 1.0 & 1.2 & $0-2$ & 0.1 & 0.1 & $0-0.1$ & 38.7 & \\
& Reference & & & & & & & & \\
\multirow{3}{*}{ PIMO } & Contemporary & 4.0 & 6.9 & $0-12$ & 0.3 & 0.9 & $0-0.6$ & 41.4 & 21.7 & $28.8-54.0$ \\
& Reference & 2.60 & 4.6 & $0-8$ & 1.1 & 1.9 & $0-3.3$ & 111.8 & \\
\multirow{2}{*}{ Total } & Contemporary & $617.0^{*}$ & 366.0 & $204-860$ & 47.8 & 18.9 & $26.1-59.6$ & $30.4^{*}$ & 5.7 & $26.1-36.9$ \\
& Reference & $186.0^{*}$ & 85.7 & $98-266$ & 59.7 & 87.6 & $37.6-93.5$ & $62.4^{*}$ & 6.4 & $55.0-66.4$
\end{tabular}


S4. Mean simulated fire behavior under $80^{\text {th }}, 90^{\text {th }}$, and $98^{\text {th }}$ percentile weather conditions for reference and contemporary forests in the Lake Tahoe Basin, USA. Fire types are surface (S), passive crown (PC), and active crown (AC). ${ }^{\mathrm{a}}$ Fuel model from Scott and Burgan (2005). ${ }^{\mathrm{e}}$ Fuel model from Anderson (1982). Pairs of reference and contemporary conditions for a fire behavior variable with the same letter were significantly different (Kruskal-Wallis $\mathrm{H}$ test, ${ }^{\mathrm{a}} \mathrm{P}<0.05,{ }^{\mathrm{b}} \mathrm{P}<0.01,{ }^{\mathrm{c}} \mathrm{P}<0.001$ )

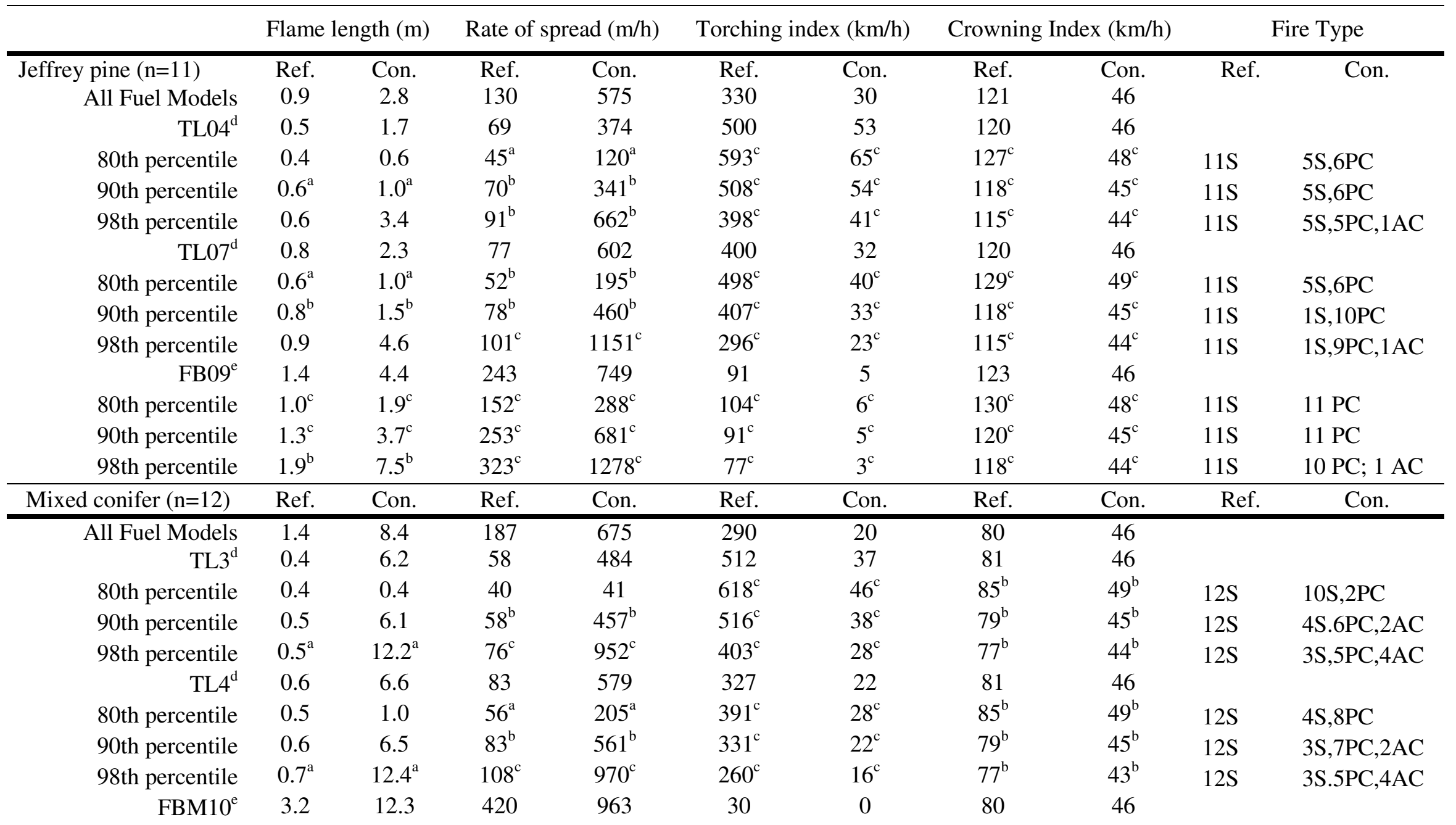




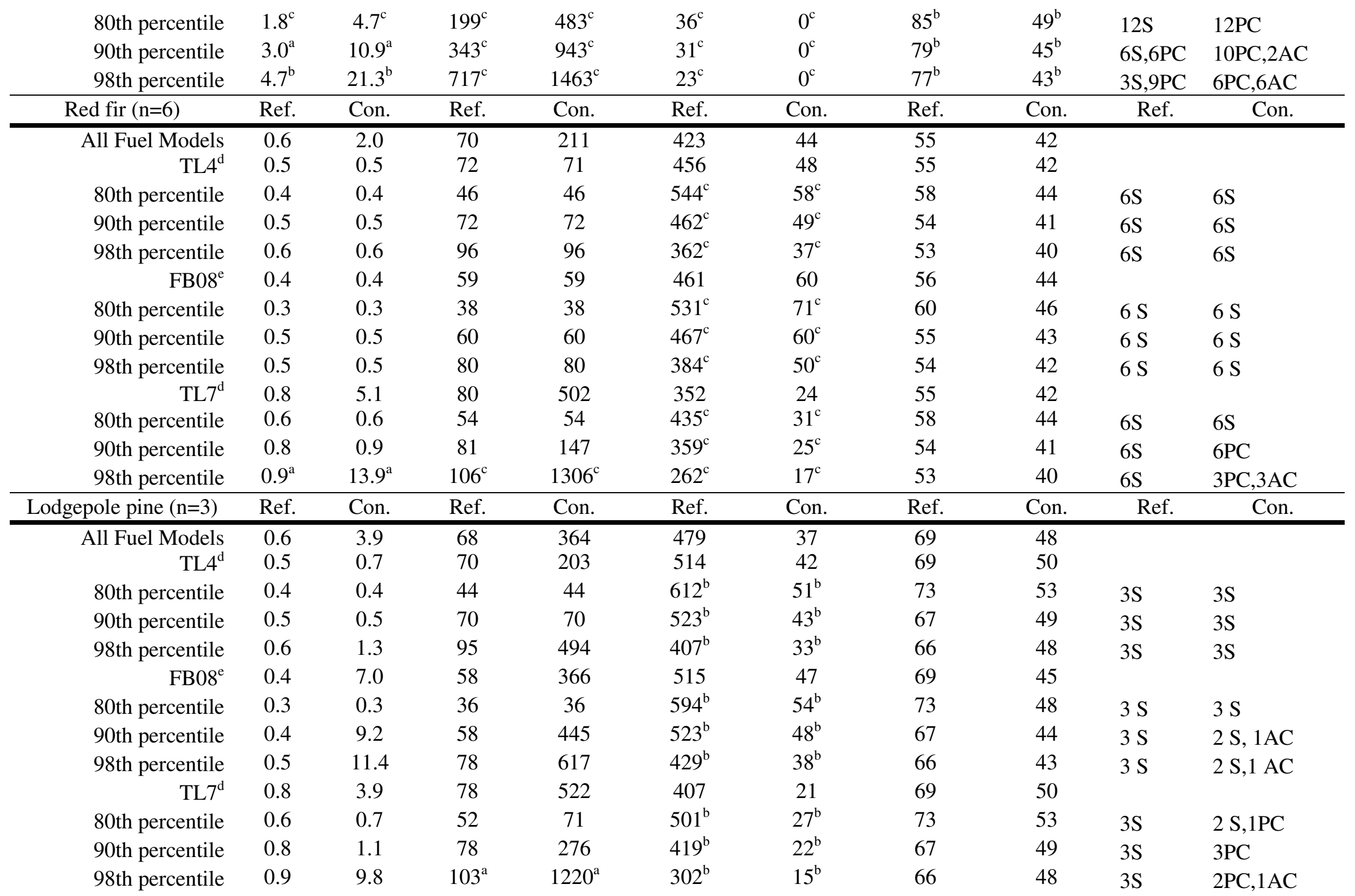

